NOAA Technical Report NMFS Circular 446

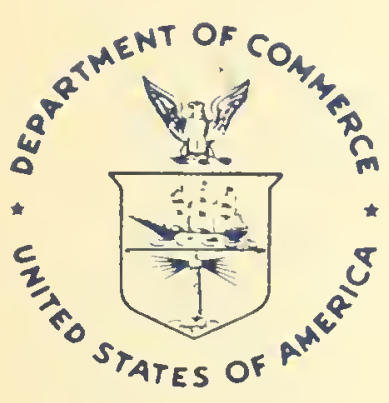

\title{
Marine Flora and Fauna of the Northeastern United States. Lichens (Ascomycetes) of the Intertidal Region
}

Ronald M. Taylor

August 1982 


\title{
NOAA TECHNICAL REPORTS
}

\author{
National Marine Fisheries Service, Circulars
}

\begin{abstract}
The major responsthilutes of the Natınal Murine Fisheries Service (NMFS) are to monitor and assess the abundance and geographic distribution of fishery resources, (1) understand and predut fluctuations in the quantity and distribution of the se resources, and to establish levels for optımum use of the resources. NMFS is also charged w th the development and implementation of policies tor managing natıonal ishing grounds, development and enforcement of domestic

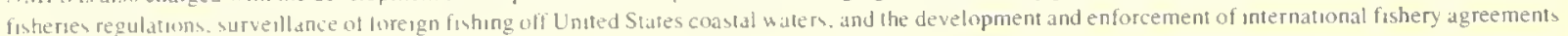
and pollicies NMFS aluw awists the fishing industry through narketing service and economic analy us programs. and mortgage insurance and vessel consinictron subsidies It collecis, andyzes, and publishes statistics on sunous phases of the industry

The NOAA Technical Repuri NMFS Circular sertes continues a senes that has been in existence since 19dI The Circulars are technical publications of general interevintended to ard conservation and management Puhlkations that rewew in considerable detal and at a high technical level certarn broad areas of research appear in this senes Technical papers originating in economics studies and from management investigations appear in the Circular senes

NOAA Technical Report NMFS Circulars are avalable free in limited numbers to governmental agencies, both Federal and State They are also avalable in exchange for wher scientific and technical publication in the marane sciences Individual copres may be ohtained (unless otherwise noted) from D822, User Serixes Branch. Environmental Science Information Center. NOAA. Rochville. MD 20852 Recent Circulars are
\end{abstract}

118 Annotaled brblography of four Ailantic seimbrids Siomberomorus brasiltensis, $S$ cavillu, S. maculatis. and S regals, by Charles S Manooch III. Eugene 1. Vahamura. and Ann Bow man Hall December 1978, 1i1 +166p

419 Murne flora and funna of the northeavtern Unted Sidtes Protozoa Sarco-

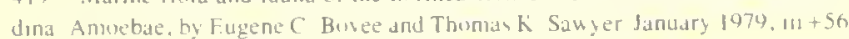
p. 77 figs For sale by the Superintendent of Doxuments. U S Guvernment Pnnting Office. Washington. D C 2(240)?. Soch No 1003-017-0043.3-3

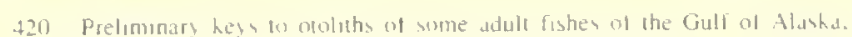
Bering Sea, and Beautort Sead, hy lames E Murnou Febriary $14791.1+32 \mathrm{p}, 4 \mathrm{pl}$

421 Larval deselopment of hallow water barnacles of the Carolinas (Cirripedia

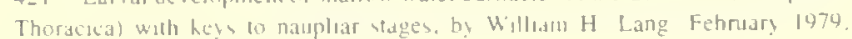
11 +39 p. 36 igg, 17 tublew

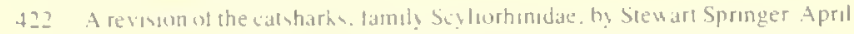
1979. 1 +1\$2 n. 97 figs For ule hy the Superintendent of Documents. US Gov.

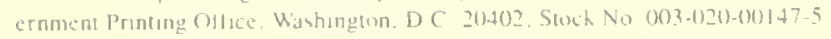

423 Marne flora and taund of the mortheatern Lnited Stuten Cruvdaced Cuma

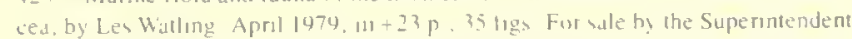
of Dixuments, I s Government Printung (oflice. Washungton. DC 2040)2, Stuch No) $(16) 3(0) 17004+46-5$

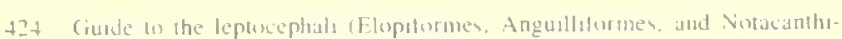
formes. by Dowid G Smith July 1979. $11+39$ P. 54 lige

t25 Marme llora and launa of the nurtheastern Linted Stales Arthrupedd Carrpedid, by Victor A Zulto Aptol 1979, $111+29$ p. 41) f19 For wale by the Superm-

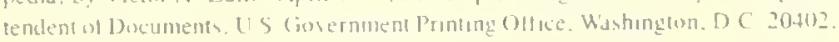
Suck No 003017 (K) $453-8$

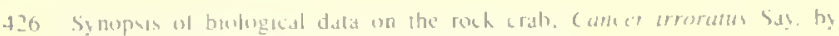

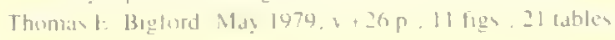

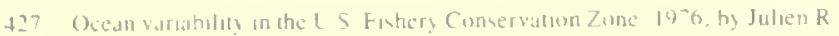

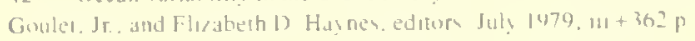

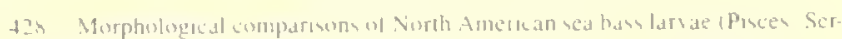

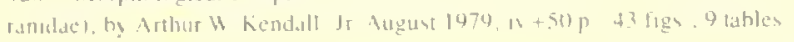

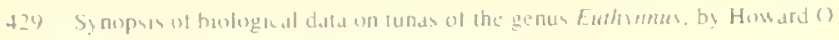

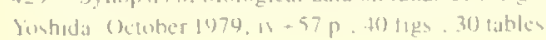

430 Guide 10 idencification of some sculptn (Collidae) larvac from marine and brackish waters off Oregon and adjacent areas in the northeast Pacific. by Sally $L$. Richardsun and Betsy B Washington January 1980. 1s +56 p. 32 ligs. 45 tables.

431 Gunde 10 some trawl-caught manne fishes Irom Masne to Cape Hatteras. North Carolina, hy Donald D Flescher March 1980. $11+3.4$.

432 Sy nopes of biologkal data un homitos of the genus Surda, by How ard O. boshida May 1980. it +50 p. 43 figs. . 20 tables

433 Sy nopsis of biclogical data on unped bass. Morome saxutlis (Walbaum). by Eleen M Sezzler. Walter R Buynton. Kathry n V Wood. Henry H Zion. Lawrence Lubbers. Nancy $k$ Mountiord. Phyllis Frere. Luther Tucker, and Joseph A Mihurshy June $1980 . v+69$ p. 9 figs. 24 tables

434 Oveologs, phylogens. and higher clasufication of the lishes of the Order Plectognathi (Tetratuduntuformes), by Jamen $C$ Tyler Outuher 1950, xu+422 p. 326 figs. 3 tables

435 Field guide 20 fishes commonly taken in longline operatıons in the western Nurth Ailantic Ocean, by Joxeph L Ruwo January 1981. $13+51$ r . 58 ligs

4.36 S: nupsis of hulngscal data on frigate tuna. Auss thazard, and hullet tuna. A.

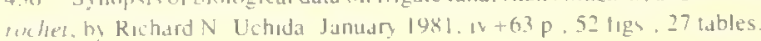

437 Fishery publuaton index, 1975.79, hy Lee C Thorsun M1dy 1981. $111+117$ $p$

438 Marine flora and fauna of the northeastern United States Scleractuma. by Siephen D Carna July 1981. $111+15$ p. 16 fig 2 iables

430 Marne llora and faunj of the northedstern Unted Stutes Protozoa Sarco. dind henthic Foraminifera, by Ruth Todd and Doris Lus June 1981, 111+51 p.. 23 tigs

440 Marine llora and launa of the northeastern Unted States. Turhellaria Acoela and Nemertiodermalida, by Louse F Bush luly 1981 . $111+71$ P. 18.4 figs

4.41 Si nopus at the bushgy of the suordinh, Xiphas gladus Linnaeus, hy B J Palko, G L Beardwey. and W J Rkhards Novemher 1981, 心 +21 $\Gamma, 12$ figs, 5 lables

4.42 Praceedings wh the Sivth LS Japan Mceting on Aquatulture. Santa Barbara. Calılorna. Augus 27-28, 1977, by Carl J Sindermann feditor) Murch 1982, $113+66 \mathrm{p}$ 
NOAA Technical Report NMFS Circular 446

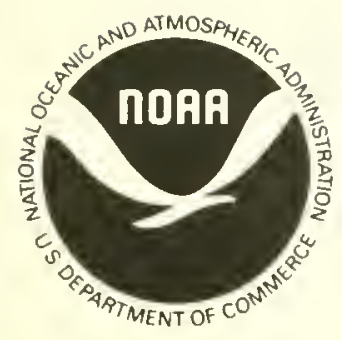

\section{Marine Flora and Fauna of the Northeastern United States. Lichens (Ascomycetes) of the Intertidal Region}

Ronald M. Taylor

August 1982

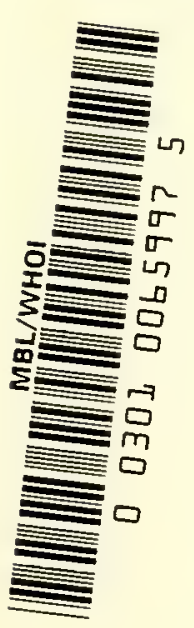

U.S. DEPARTMENT OF COMMERCE

Malcolm Baldridge, Secretary

National Oceanic and Atmospheric Administration

John V. Byrne, Admınistrator

National Marine Fisheries Service

William G. Gordon, Assistant Administrator for Fisheries 


\section{FOREWORD}

This NMFS Circular is part of the subsenes "Marne Flora and Fauna of the Northeastern United States," which consists of onginal, illustrated, modern manuals on the identificatton, classufication, and general brology of the estuanne and coastal manne plants and anmals of the northeastern United States The manuals are published at uregular intervals on as many taxa of the region as there are specialists avaslable to collaborate in their preparation

Geographic coverage of the "Manne Flora and Fauna of the Northeastern United States" ds planned to include organisnu from the headwaters of estuanes seau ard to approxumately the $200 \mathrm{~m}$ depth on the continental shelf from Maine to Virginua, but may vary some hat with each major taxon and the interests of collaborators. Whenever possible representative specimens dealt with in the manuals are deposited in the reference collections of najor museums of the region

The "Marine Flora and Fauna of the Northeastern Unted State" "1s being prepared in collaboration with systematic specialists in the United States and ahroad. Each manual is based promarily on recent and ongoing revisionary systenatse research and a fresh examınatın of the plants and anımals. Each major taxon, treated in a separate manual, includes an incroduction. illustrated glossary, unform ongunally illustrated hey s, annotated checklist with information when available on distribution, habitat, life history, and related biology, references to the major literature of the group, and a systematic indes.

These manuals are intended for use by biology students. biologists. blological oceanographers. informed laymen, and others wishing to identify coastal organisms for this region. Often they can werve as guides to additional information about species or groups.

The manuals are an outgrou th of the undely used "Keys to Manne Invertebrates of the Woods Hole Region." edited by R. I. Snith in 1964. and produced under the auspices of the Systematics Ecology Program, Marine Biological Laboratory. Woods Hole. Mass After a sufficient number of manuals of related taxonomic groups have been published. the manuals will be revised, grouped, and issued as spectal rolumes, which will consist of compilations tor phy la or groups ol phyla. 
CONTENTS

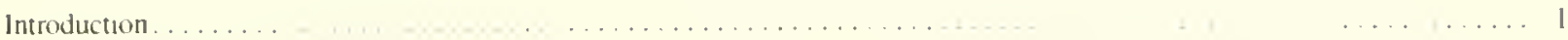

Methods of collection and studying. . . . . . . . . . . . . . . . . . . . . . . . . . . . . . . . . . .

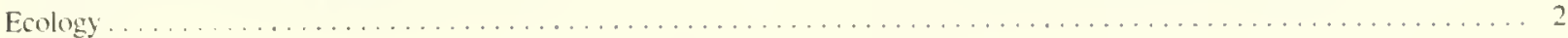

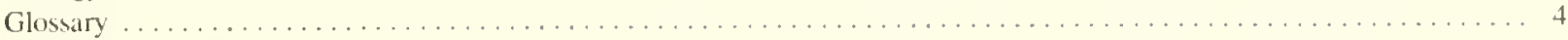

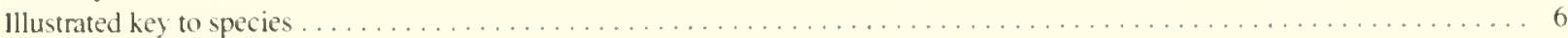

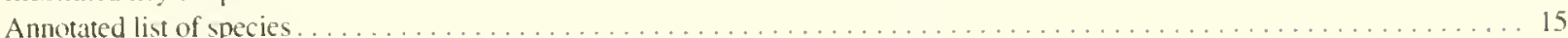

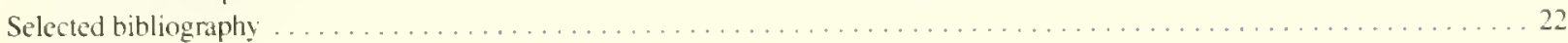

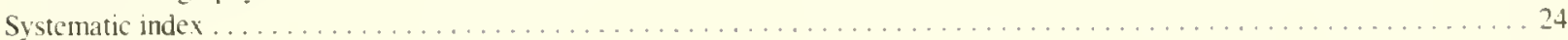

Acknowledgments . . . . . . . . . . . . . . . . . . . . . . . . . . . . . . . . . . . . . . .

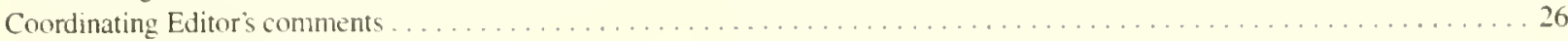

The National Marine Fisheries Service (NMFS) does not approve, recommend or endorse any proprietary product or proprietary material mentioned in this publication. No reference shall be made to NMFS, or to this publication furnished by NMFS, in any advertising or sales promotion which would indicate or imply that NMFS approves, recommends or endorses any proprietary product or proprietary material mentioned herein, or which has as its purpose an intent to cause directly or indirectly the advertised product to be used or purchased because of this NMFS publication. 


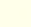

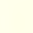

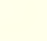

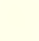

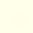

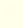




\title{
Marine Flora and Fauna of the Northeastern United States. Lichens (Ascomycetes) of the Intertidal Region
}

\author{
RONALD M. TAYLOR
}

\begin{abstract}
This mantal tredts the Irehena found in the intertidal region trom New Jeraes to New foundland Methode of callection. preparation. and sudy are hrietly efeated. Twenty-tuo upecies are cosered, hoth in an illustrated hes

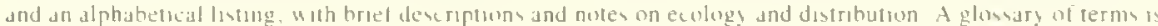
included
\end{abstract}

\section{INTRODLCTIOY}

The content and sty le of this paper are intended to encourage and verve all who might wish to study the lichens of the fascinating and comples marine littoral environment. It is evident from the literature and from inquiries directed to the author that the marine lichen flora presents an interesting enigma to biologists of diverse disciplines. It is hoped that this paper will help them in studying, recognizing, and accurately reporting the lichens of the littoral zone.

A lichen is not "a plant" but rather a life or growth form comprised of two kinds of plants. a fungus and an alga. growing together in a symbiotic relationship. Although hotamsts differ as to the evact nature of the $: y$ mbiotic relationship. each member of the relationship seens to benefit from the other. In reality, there are probably different kinds of relationships in different lichens. Most lichens are fungus dominated, i.e., the shape and most of the mas. of the lichen is derived from the fungus. All the marine lichen treated in this manual, except for the genus Lichina, are fungus dominated and the fungus is an Ascomycete.

Marne lichens occur in three growth forms: fruticose. foliose, and crustose. Fruticose forms are usually upright or pendant in relationship to the substrate: they stand out away from the substrate. Lichima, the only genus of fruticose lichens in the littoral region grows in a shrublike form. Foliose forms, as the name implies. have a leafy appearance, often in rosette form. and may be removed from the substrate. The only genus of foliose lichens in the hittoral region is Xamthoria. Crustose forms often appear as discolored areas on rocks and are usually destroyed if one attempts to remerve them from the substrate. They may be shiny or dull, black. green. or brown. Most manne lichens are crustose and grom on rochs: one species. Arthoprenia halodyes, grows on barnacles

Lichens mas be found in a continuous range of habitats. from low tide to mountain tops. The species included in this manual are those found in the intertidal zone plus the nurmal spray zone but not what is often called the "storm spray zone."

Some of the lichen in this manual are obligate marine lichens. 1.e. they grow only where they are struch directly by saltwater. Others are facultative, heing found also in areas remote from the sea. My criterion for including a facultative lichen is its occurrence with. or at the same height on the shore as, an obligate marine specias.

Science Deparument Lanung Communut College Lameng M11 48914

\section{METHOJS OF COLLECTION AND STUDYING}

Manne lichens inhabit rocks or the barnacles attached to them. Most littoral lichens are crustose and cannot he removed from the rocks without heing destroyed. They must be collected along with a piece of the rock substrate. using rock chisels and a 3-lb hammer. Ideally one should strive to collect specimens on pieces of roch small enough to fit well into $4^{\prime \prime}$ " 0 " herbarium packets. This will not always be possible because the lichen may grow on an irregular piece of roch that does not break easily. Further preparation can be done in the Jaboratory, but it is usually easier to reduce the size of a rock in the field

Once the specimen is removed it must be placed in a suitable container. Paper bags are quite satisfactory if the bag is strong. Unfortunately. the specimens are often wet, and the wet bag may need to be placed in another bag. Plastic or other waterproof bags are not desirable snce they retard drying and promote molding. If a waterproof bag is used in the field, the specimen should be transferred to a paper bag and air dried within a day of collection.

A rock saw would seem to provide a fairly ideal solution to the prohlem of shaping rochs for herbarium packets in the laboratory. However. the use of a rock sau requires a liquid coolant to protect the blade. In preparing lichen specimens, water should be used rather than the oil employed in lapidary work. This works well with nonlittoral specimens. but with littoral lichens the soaking that results from the water coolant and the additional water required to rinse the specimen causes excessive reticulation that is detrimental to future study.

Hydraulic devices are available which break rocks by applying pressure to chisellike jaws. These produce fractures in the rocks that are not as neat or predictahle as the cut of a sau but they do avoid reticulation and are quite satisfactory.

After sizing, the rochs should be glued to cards of suitable size. This prevents abrasion of the specimens and degradation of the rock. Also. it provites a way to permanently identify the rock fragments examined for the lichen in question.

Many of the diagnostic characteristics of littoral Jichens are readily observed with a dissecting microsiope at a magnification of 20 power. Bright illumination is important because of the dark color of many thalli, especially in the genus lemucara. Thalli shoutd be ohserved in both wet and dry conditions. Water added to the thallus sparingly to asoid unnatural reticulation often increases its trans parency, thus revealing subsurface patterns. 
Sections of fruiting structures may be made by hand with a razor blade. The small size of the perithecia of many specres of Verruearia are difficult but not impossible to section. A double edged razor blade, broken lengthwise, is most suitable.

Microtome sections are complicated by the thin crustose nature of the thalli and their adherence to the rock substrate. Furthermore the involucrella of pyrenocarpous lichens are hard and brittle and do not respond well to the usual paraffin imbedding techniques.

Two techniques employing a freezing microtome are satisfaetory. One technique involves pouring a shallow layer of agar in a small container. The perithecium is moistened several times with water containing a small amount of wetting agent, such as alcohol. The perithecium and the subtending and surrounding thallus are then scooped from the rock with a razor blade, taking care to lift the entire perithecium from the rock. Faulty dagnosis will result if the base of the perthecium is left on the roek. The thallus and perithecium are then translerred to the surface of the agar. A drop of melted agar placed over the lichen material embeds it between the two layers of agar. A cube cut from the agar is then placed on the freezing microtome so that the thallus is perpendicular to the blade and the vertical axis of the perithecium is parallel to the blade. The material is then frozen and sectioned

The other teehnique involves comnercially available synthetic plastic materials intended for embedding frozen sections. A mound is built up on the microtome's object dise and frozen. A vertical face is cut facing and perpendicular to the blade. The lichen material to be cut is prepared as before and then pressed firmly against the embedding material. The pressure melts the plastic and when the pressure is released the plastic and embedding lichen fuse and Ireeze solid.

Both techniques have the disadvantage of leaving visible residues on the slide surrounding the sections. This is a problem only if the slide is to be photographed.

Some species of lichens give a color reaction to potassium hydroxide. A drop of $10 \%$ solution is applied with a dropping pipette or capillary tube, directly to the cortex, or to medulla exposed by fragmentation or an incision.

Santesson (1939) described a number of environmentally induced morphological variations in littoral lichens in general and described in detail the variations of eertain selected species. Both Weber (1962) and Santesson (1939) have emphasized the importance of understanding the range of vanation induced by the environment.

The auther has traced variations of single thalli from continuous to areolate and from smooth to ridged. The author has also observed variations of perithecia from sunken to prominently raised on a single thallus. Even the darkness of the lower side of the excipulum (inner lining of perithecium) is quite variable withın a single species. Shade modification is well known and predictable among littoral lichens. Shade causes lighter pigmentation and reduction in size and number of juga (blach pegs, lumps, or ndges protruding from the surface). Some species that are distunct in appearance when growng in good illumination appear much less distinet when growing in the shade. The distinguishing features of a species are frequently reduced by the shade modification. As a result there is considerable taxonomic conlusion among the shade modifications of lemucaria striatula, $V$. dimarsica, and, to a lesser degree. I: erichsenii. Ton much stress can be placed on perithecium size. Variations of perithecium size on a single thallus beyond the range accepted in some taxonomic keys have been observed. Thus the taxonomic eharacter "perithecia slightly smaller (or larger) than .." should be regarded with suspicion
If one's study is restricted to a few specimens, it is easy to see dichotomy among the species examined. As the number of specimens increases, the kinds and degrees of variations also increase and extreme forms are bridged by lesser variations. Since the littoral environment is one of great physical contrasts and many mitrohahitats, it is not suprining that considerable taxonomically confusing variations in the lichens have resulted.

\section{ECOLOGY}

Between low and high tide marks the rocks of the shore are largely covered by macroaglae such as Fucus sp. Among the holdlasts of such algae, the marine lichens compete for space with barnacles, Bryozoa, and such algae as Hildenbramsia and Lithothamnia. The lichen Arthopyrenia halodyes often occupies the shells of the barnacles with which the other lichens compete. Perithecia, the cone-like fruiting structures of marine lichens, are often seen protruding through the thalli of Hildenbrantia or Lithothammia which have overgrown them. Such competition with the lichen lerrucaria mucosa has mixed results: either the lichen or the alga may establish itself on top. Only the lichen genera Arthopyrenia, Srigmidimm, and lermuariu are found throughout this zone of the shore. The lermoraria species Imara and centhocarpa do not extend very far down into this zone

From the high side mark upward for about $0.5 \mathrm{~m}$ is the barnacle belt. The barnacles are so successful in the competition for space that only their shells are available as a substrate lor lichens. The lichen Arthopyrenia hatodytes is found here in pits dissolved into the barnacle shells.

Extending upward from the barnacle belt is the black belt populated by various species of termcuria in competition with bluegreen algae. especially of the genus Calothris.

Investigators in northern Europe find a well delined orange belt above the black belt and a whte "Ramalima bett" above that In northeastern North America the orange belt is intermittent or absent and the "Ramalina belt" is entirely absent. The orange belt. where present. is comprised of members of the genera Calophaca and Ximthoria. Lichina confinis, a black fruticose lichen, may be lound in this belt or extending down to the black belt. Various other lichens may extend into the orange belt but in the fex and incomplete orange betts encountered in northeastern North Amenea by the author, only Lecanora grantii, a gray crustose lichen with euplike fruiting bodies, was found. Nothng above the orange belt was considered in this study because it is the highest wne to contain obligate marine lichens.

The lichen flora collected at the northern end of the sudy range was comprised of 22 species. At the southern end ol the range the lichen flora was reduced to two species. In an attempt to explain the distribution in terms of environmental cause, a multple regression analysis was used to assess the impact of environmental factors on the suceess of individual species and on the general diversity of species. The environmental factors whose individual and interactive elfects were computed are: salinity, aur and water temperatures. solar insolation, and idal range. No simple answers emerged either for the suceess of any species or for general diversity. However by tallying the number of times that each environmental factor was involved as one of the most important influences, the following frequencier resulted: salımty, 21: insolation. 15: air temperature, 12, tidal range. 7; and water temperature, 2.

Where sutficient collectrons were made to provide adequate data, vertical distributions of the various manne lichens were graphed (Figs. 1-8). In these graphs the extent above mean high 


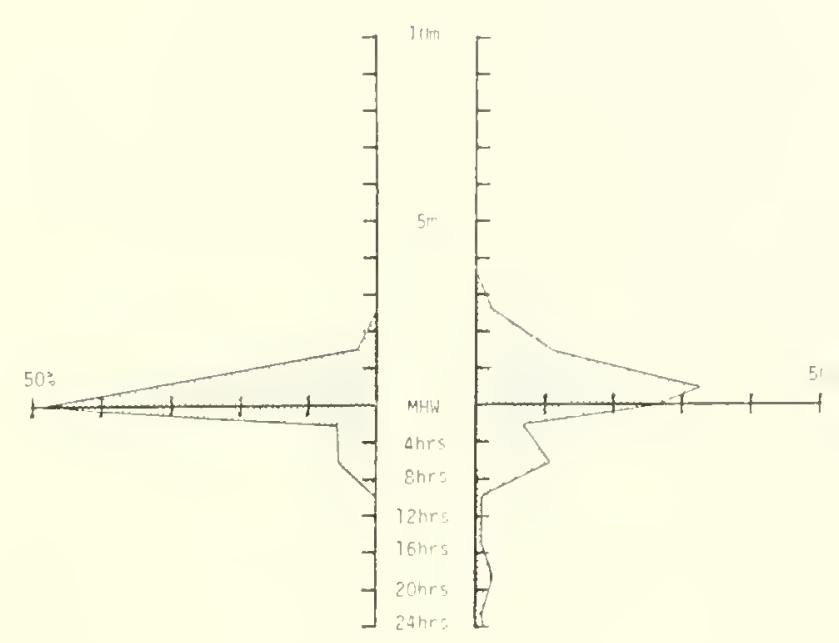

Figure 1.-Vertical distribution of Arshopyrenia halodyres.

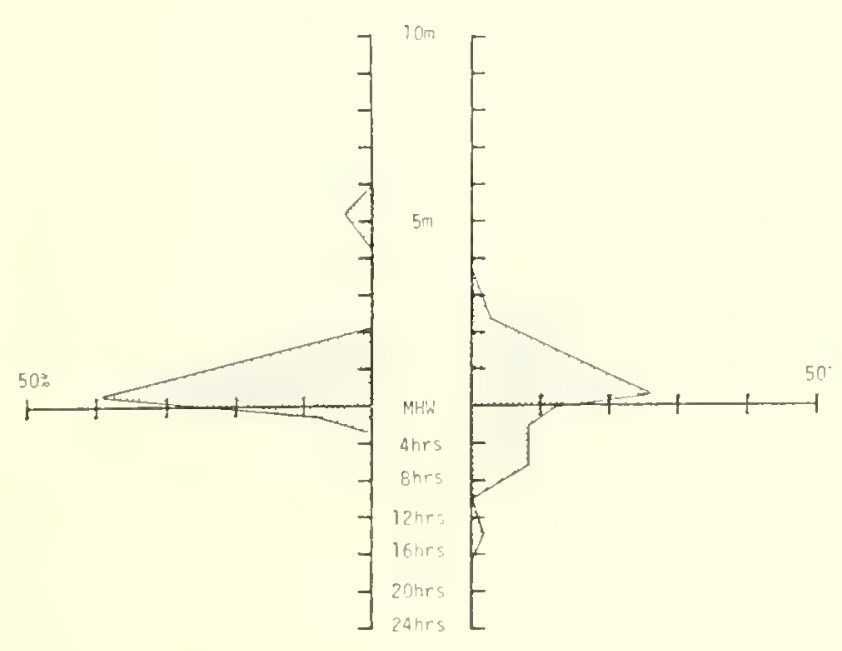

Figure 2.-Vertical distribution of lerrucaria degelii.

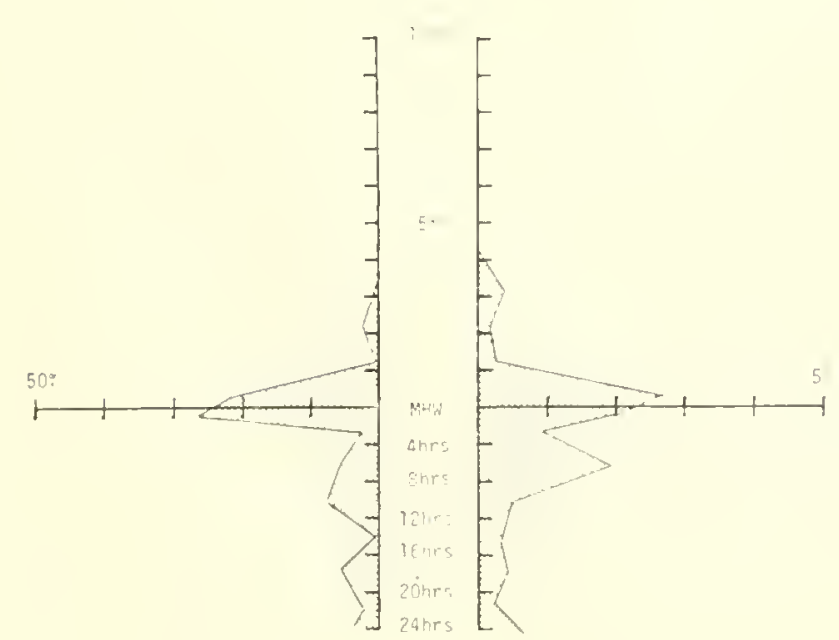

Figure 3.-Vertical distribution of lerracaria dimarsica.

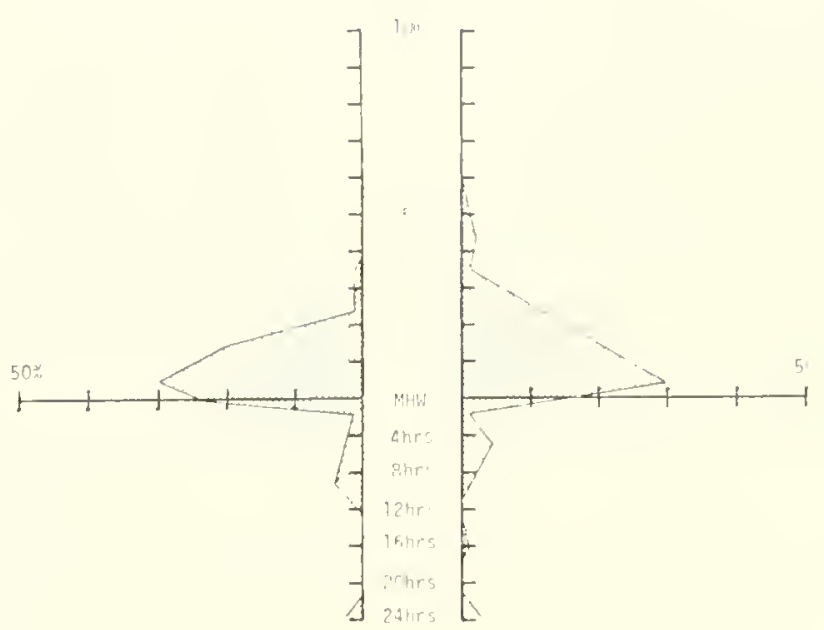

Figure 4. - Vertical distribution of lerrucaria erichseni.

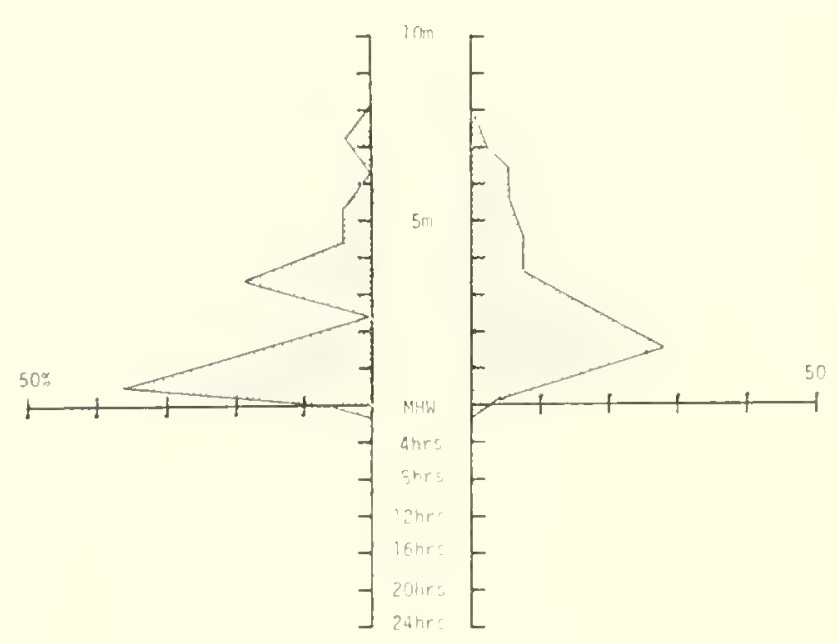

Figure 5.- Vertical distribution of lerracaria maura.

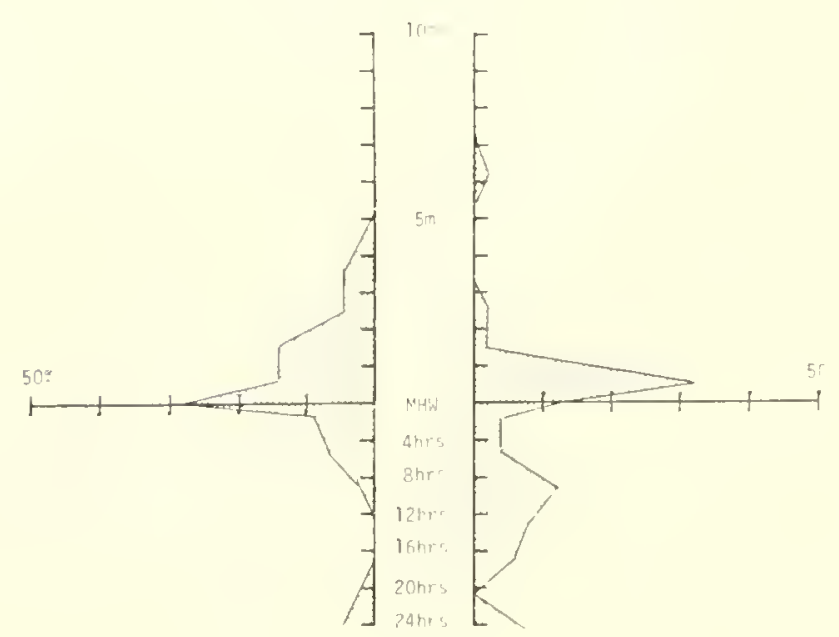

Figure 6.- Vertical distrihution of Verrucaria microspora. 


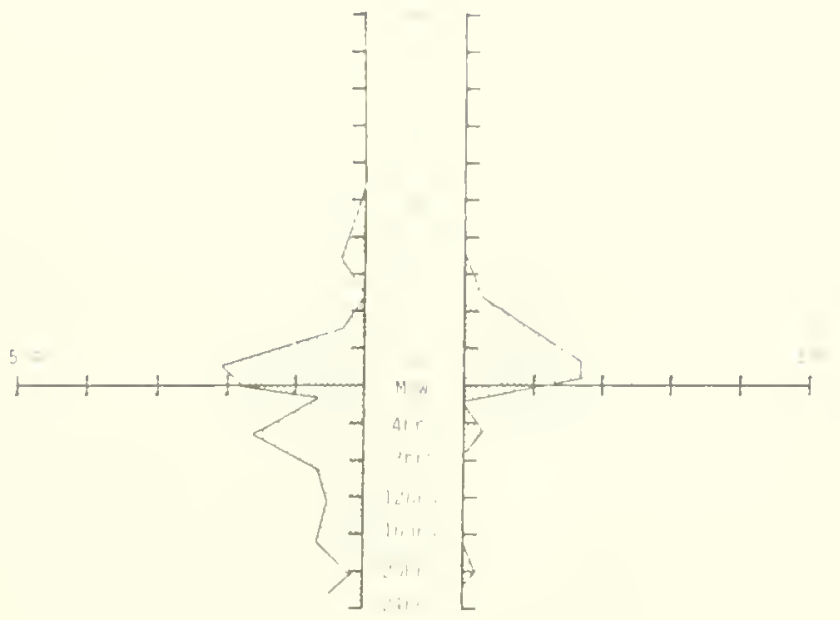

Figure 7.- Vertical dislrihulion of lerracaria mucosa.

tude is given in meters. Due to the great variation in the distance hetween mean low tide and mean high tide (ca. I $1010 \mathrm{~m}$ ), the distance below high tide is given in hours of submergence. Each interval on the $\mathbb{X}$-axis represents $10 \%$ of the total collections of that species by the author. In each ligure the graph on the right represents the vertical distribution on exposed shores and the griph on the left represents the vertical distribution on sheltered shores.

\section{GLOSSARY}

The use of lichenological terminology in this publication has heen reduced to a minimum. Several terms are illustrated as well as defined

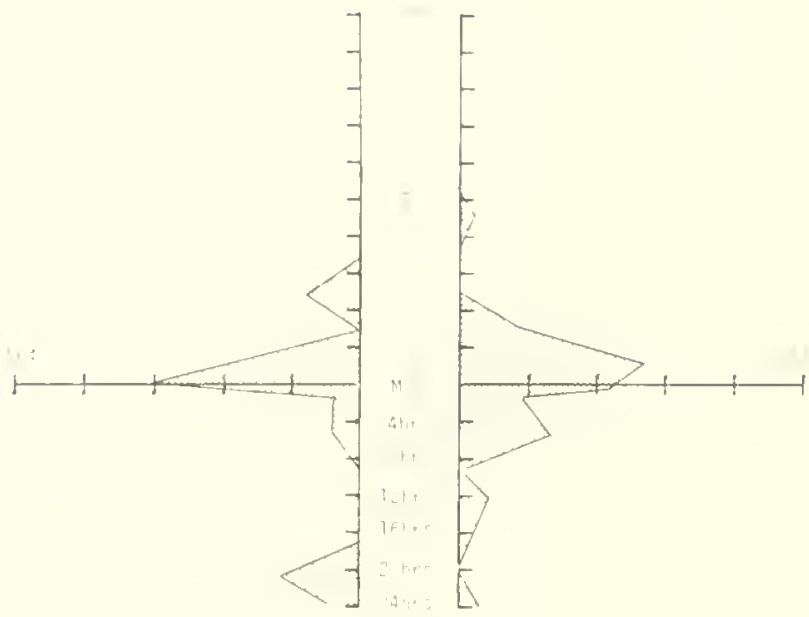

Figure 8.- Vertical divtrihution of Verracaria stratula.

Aprical At the tip or aper (Fig. 9).

Aprethecium (pl. Apeshecies) Disc, saucer or cup shaped frusting body (Fig. 9).

Areolatc Broken hy clefts into small, usually angular and irregular patches (arcoles)

Areole (pl. Areoles) Area of a thallus divided from the rest of the thallus by fissures (Fig. 10)

Arè (pl. Arètes) Sharp peak elevated above a ridge

Ascocarp (pl. Ascrearp) An Ascomycete frustung budy giving tre to and containing asci and ascospores (Figs. 9. 10)

Ascus (pl. Asci) A sack-like structure whin which ascospores are formed and contained in the ascocarp (Fig. 10 .

Carbonaceons Made up largely of carbon deponts

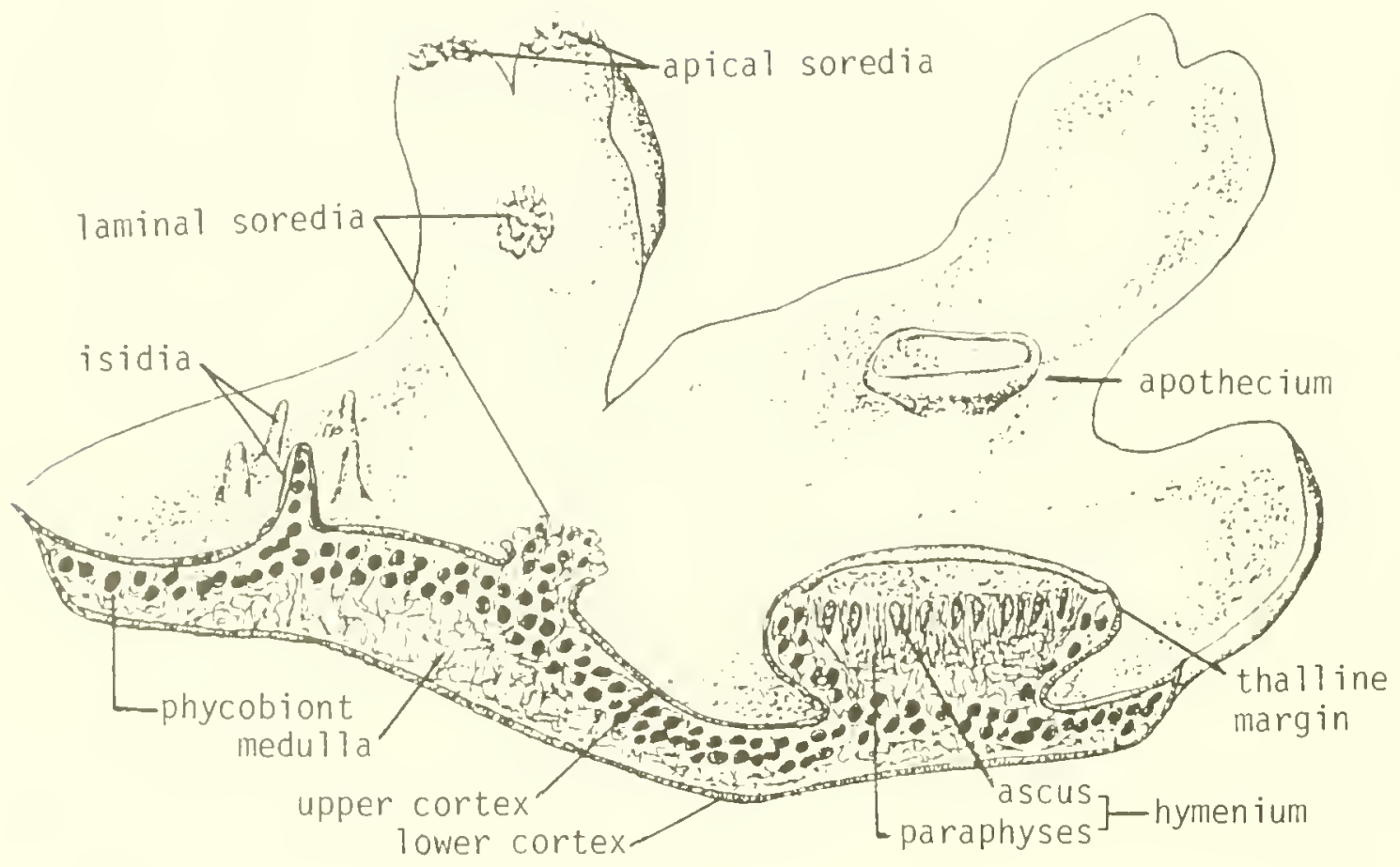

Figure "). - C'omposite follose lichen with apol hecia 
Citrine Lemon yellow colon

Conidium ( $\mathrm{pl}$. Comidia) Asexual reproductive spores of Ascomycete

Comimum Thallus unbrohen hy gaps or fissures.

Cortex (pl. Cortices or Cortexes) The compact outermost fungal layer of a lichen thallus (Figs. 9. 10).

Cratcrous Havng a depression resemhling the crater of a votcano.

Cremulate Having small rounded lobes.

Crustose A type of thallus which usually adheres tightly to the substrate and cannot he removed from it without destruction of the thallus: lacks a lower cortes and thizines (Fig. I0).

Cusp) (pl. Cusps) Crexcent shaped mound.

Dendritic Having a pattern resembling the branching of at tree limb.

Dispersed Scattered.

Endolithic Growing wathin the rock substrate.

Epithecium (pl. Epithecia) Coverng of the hymenium

Everginate To protrude as if a pocket turned inside-out.

Excipulum (pl. Excipula) As used here, the inner wall of a penthecium.

Foliose A type of thallus, leaflike or lohed, often with rhizines or hairlike processes on lower surface, usually with lower cortex. algal layer limited to upper side (Fig. 9).

Fruticose A type of thallus that is shrublike, stalked, or pendant with the algal layer usually on all sides.

Fusiform Narrowed both ways from a swollen middle.

Glabrous Having a smooth even surface.

Globose Spherical.

Holdfast (pl. Holdfasts) The basal portion of an algal thallus attaching it to the substrate.

Haline Colorless.

Himenium (pl. Himonio) The layer of the ancocarp contanning the asci and usually paraphyses (Fig. 9).

Hypothallus (pl. Hypothalli) A marginal outgrowth of hyphae from the thallus of a crustose lichen (Fig. 10).

immersed Sunken mostly or entirely below the surface of the thallus.

Inypressed Indented.

Involucrellum (pl. Imolucrella) The usually black and carbo- naceous covering of a penthecium (Fig. 10).

lsulium (pl. Isidia) Smatl cylindrical, corallond, or glohose outgrowthe of the thallus serving as vegetative disseminules. They are covered with contex and contain both fungal and algal components (Fig. 9).

Isthmus (pl Isthmuses) A narrow passage.

Jugum (pl. Juga) Protnusions of carbonaceous material extending at least partly above the thallus surface as ndges, pegs, or urregular lumps (Fig. 10).

Laminal On the flat surface of the thallus (usually upper) (Fig. 9).

Lenticular An area, pointed at each end. inclosed by two intersecung convex curves.

Linoral lichen Growing between the tides. The term is extended herein to include those struck by saltwater due to wave action and is used interchangeably with the term "marine."

Locule (pl. Locules) Chamber or cavity.

Medulla (pl. Medullae) An area of loosely packed hyphae internal to the thallus and its projections such as podetia, isidia, etc. (Figs. 9.10).

Morphotipe (pl. Morphotypes) A thallus of a given species having a different appearance than other members of the speeies.

Necral Occurring after death.

Necral reticulation A network of cracks caused by treatment and/or storage after collection.

Nodular convex Like a small rounded lump.

Oblong ellipsoid $\mathrm{n}$ the form of an elongated eircle; more elongated than the typical elipse.

Oblong ovoid In the form of an elongated oval.

Olivaceous Having a color similar to that of a green olive.

Orbicular Spherical or nearly so.

Ostiole (pl. Ostioles) The apical opening of a perithecium (Fig. $10)$.

Paraphysis (pl. Paraphyses) Sterile hyphae intermingled with asci in the hymenium of an ascocarp (Figs, 9, 10).

Parasymbiont (pl. Parasymbionts) An organism living in harmless association with another without mutual benefit.

Pendant Dangling.

Perithecoid In the shape of a perithecium.

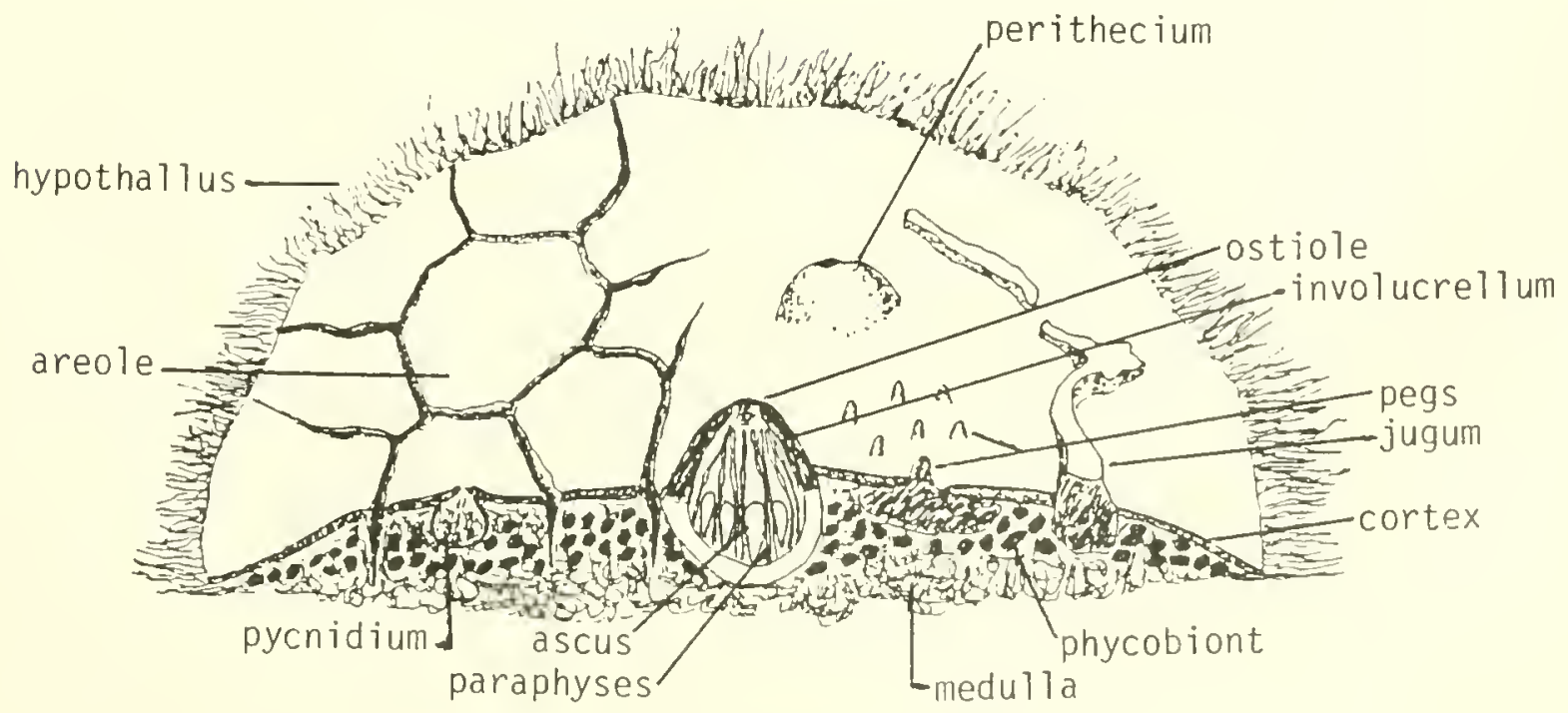

Figure 10.-Composite crusbone Jichen with perithecia. 
Perithecium (pl. Perithecia) A flash-shaped ascocarp enclosed except for the apical pore (ostiole). It is usually more or less sunken into the thallus (Fig. 10).

Phrcobiom (pl. Phycohioms) The algal member of the lichen symbiosis (Figs. 9, 10).

Pseudosemum (pl. Pseudosepta) Appearing to be an internal wall but not composed ol the same material forming the cell wall

Pycnidium (pl Pycniclia) Snall flask-shaped to glohular structures resembling perithecia but containing conidia instead of asci and ascospores.

Prencocarpous Having perithecia.

Pyrenolichen (pl. Prrenolichens) Lichen having perithecia (Fig. 10)

Reniform Kidney shaped

Reticulation A netlike appearance.

Rimose Having minute crachs, usually refernng to a form of areolation.

Saxicolous Growing on a rock or rock-like substrate.

Sessile Not supported by a stalk

Simple Describing a spore having a single, undivided cavity
Serediate Having soredia on the thallus.

Soredium (pl. Soredia) A means of vegetative reproduction of the lichen consistung of masses ol hyphae and therr associated algae rupturing through and not covered by or containing cortex (Fig. 9).

Spray arne (pl. zones) That area above high tide that is struch by drops of seawater resulting from the impact of waves on the rochy shore under nonstorm conditions.

Stom spray zome (pl. zones) That area, above the usual spray zone. that is sprayed with seawater only during a storm.

Subcomes Barely curved outward

Subeffuse Having boundaries that are poorly distingushed

Submerged Sunken entirely or mostly below the upper surface of the thallus.

Sulmomiliform Having constrictions at intervals giving an appearance nearly like a string of beads hut not so pronounced.

Thalline murgin (pl. margins) Apothecial rim having the same composition as the thallus (Fig. 9).

Thallus (pl. Thalli) The lichen body containing both algal and fungal components.

Titherculute Having a warty appearance.

\section{ILLUSTRATED KEY TO SPECIES}

The key is based primarily on characteristics that can be observed with a dissecting microscope at $20 \times$ magnification; in some cases observation ol spores with a compound microscope nay be required

The vertical sections of perithecia of lerrucaria species illustrated in the key are typical sections.

Because of the extrene degree of variation of species of marine lichens (especially of lerruccria), identification of species from the hey alone should be regarded as tentative until the more detailed description in the Annotated List of Species is read.

Five species from the Canadian Maritime Provinces are included even though at present they are not known from the eastern United States. At least one species, lerrucuria mama, has not been collected in the eastern United States recently but the author has seen specimens collected from the area over 50 yrago.

1 Thallus foliose (Fig. 9); always orange and $\mathrm{KOH}+$ purple

Thallus crustose (Fig. 10) only in a few species oringe and $\mathrm{KOH}+$ purple

Figure 11.-Lichina confints. Scale is 0.1 $\mathrm{mm}$.

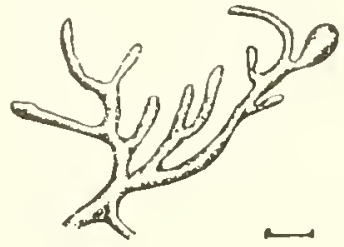

Figure 12.-Thallu of tanthoria candelaria. Scale is $1 \mathrm{~mm}$.

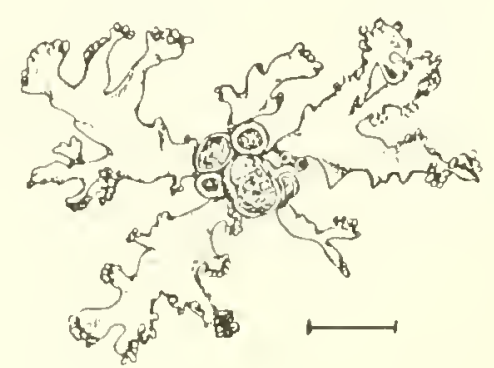


Figure 13.- Thallun of Xanthoria parietina. Scale in 1 $\mathrm{mm}$.

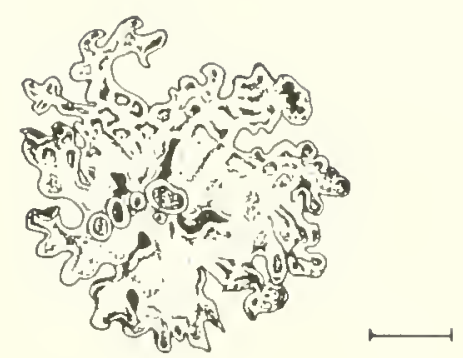

Xamhoria elegans

3 (2) Lobes nodular-convex, lobes less than $1 \mathrm{~mm}$ wide (Fig. 14)

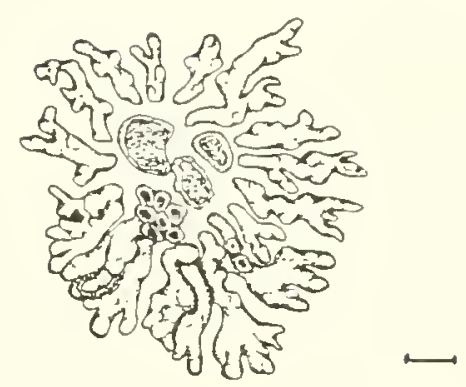

4 (/) Ascocarp an apothecium (Fig. 9); thallus light (shades of white, gray, or yellow orange).

4 (1) Ascocarp a perithecium (Fig. 10): occasionally more of less immersed with only ostiole showing: thallus dark (shades of green, brown, or black) or apparently absent

5 (4) Thallus whitish to gray, $\mathrm{KOH}+$ yellow; spores colorless, one-celled (Fig. 15), $11-18 \times 6-8.5 \mu \mathrm{m} \ldots \ldots \ldots \ldots$.......... Lecanora granti

Figure 15.-0ne-celled spore. Socalle is $111 \% \mathrm{~m}$.
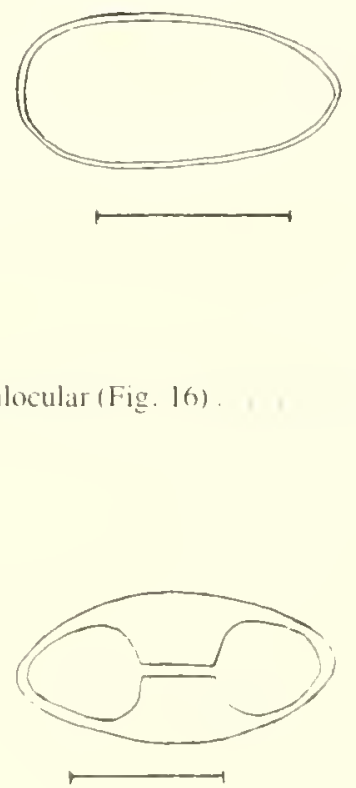
Figure 17,- Thallus of Caloplaca verruculifera. Scale in $10 \mathrm{~mm}$.

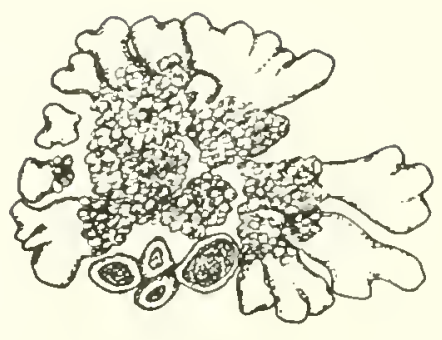

Figure 18.- Thallus of Calopiaca scopularis. scale is $10 \mathrm{~mm}$.

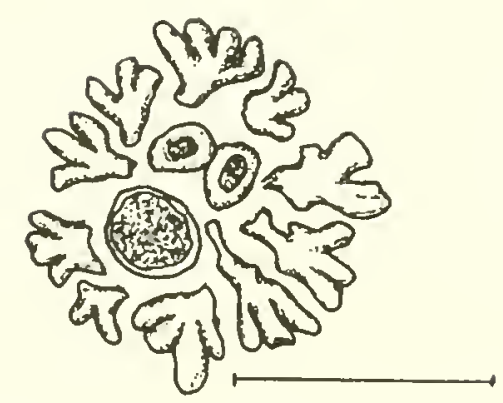

Figure 19.-I hallue of Caloplaca microthallma. scale is $10 \mathrm{~mm}$.
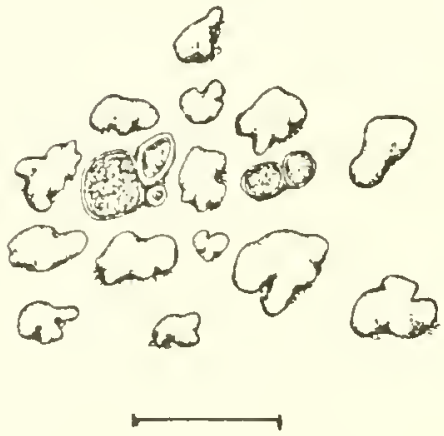

8 (7) Thallus orange yellow, marginal lobules subconves oriented in radating manner; spores $10-14 \times 5-7 \mu m$ (Fig. 20)

Pigure 20.-Thallun of Caloplaca marina. Siale is $1 \mathrm{~mm}$.

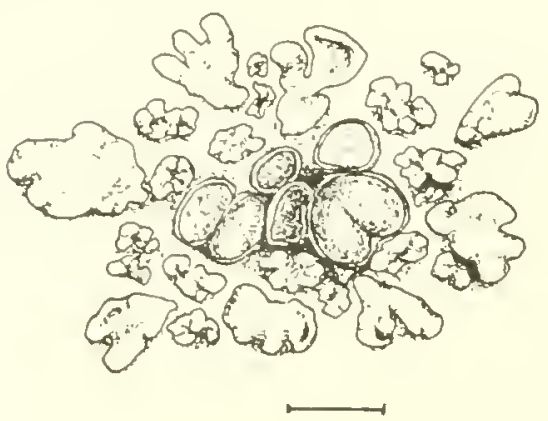


9(1) Spores more than one-celled

10 (9) Growing on thallus of lémucarias; paraphyses gelatuizing. spores $10-15 \times 3.5-5 \mu \mathrm{m}$ with 4 locules and distinct ceniral septum (Fig. 21) Stigmidium marinum

Figure 21.-Spore of Stigmidium marinum. Scale is $10 \mu \mathrm{m}$.

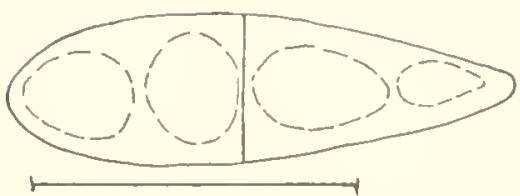

10 (9) On barnacles or roch; thallus scant to evidently lacking; paraphyses persistent, spores $9-20 \times 4-7 \mu \mathrm{m}$ with Iwo locules (Fig. 22) . . . Arthopyrenia halodves

Figure 22.-Spore of Arthopyrenia halodytes. Sicale is $10 \mu m$.

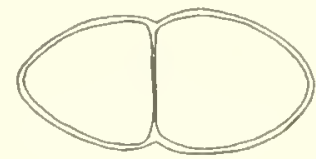

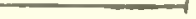

Figure 23.-a. Thallus with pegs. b. Thallus with ridges. Scate is $1 \mathrm{~mm}$

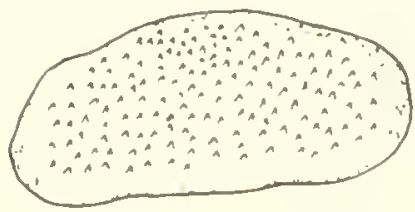

a

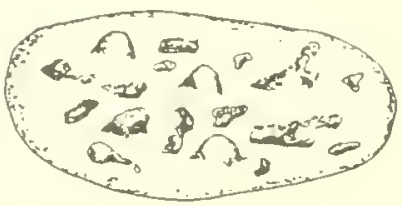

b

11 (9) Thallus smooth: pegs and ridges lacking

12 (ll) Thallus areolate (dii ided into fields by fissures. Fig. 24) ...

Figure 24.- Ireolate thallus. Scate is I mu.

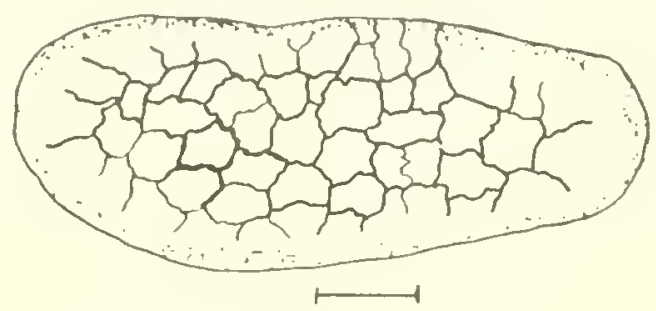

12 (11) Thallus continuous or discontinuous but not areolate (Fig. 25).
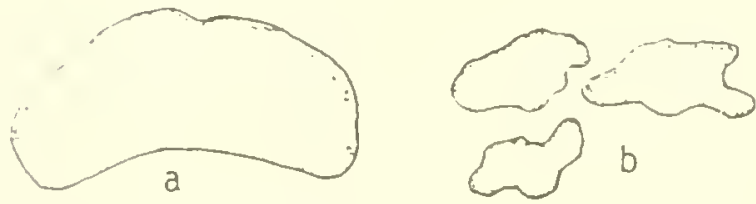

Figure 25.-a. Continuous thallus. h. Discontinumus thailus. Scale is

$1 \mathrm{~mm}$. 
Figure 26.-Thallus with chevated perithecia. scale is $1 \mathrm{~mm}$.

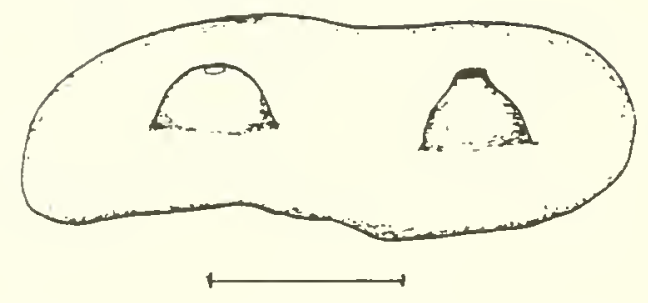

13 (12) Perithecia submerged to slightly elevated (Fig. 27); spores 8-11 $\times 4-5 \mu \mathrm{m}$; thallus thick, green to greenish-blach

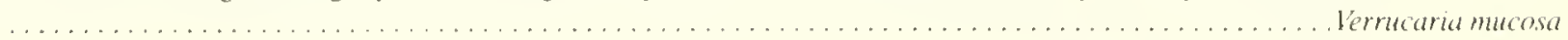

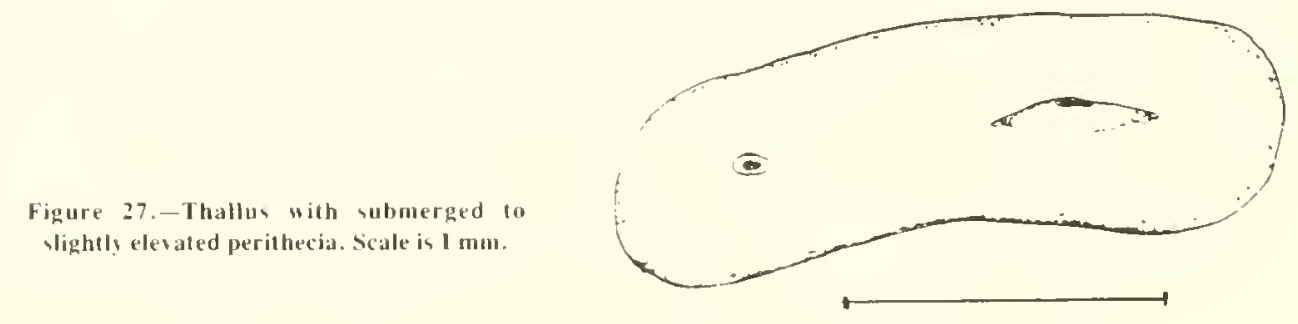

$14(13)$ Spores $6-11 \times 3-5 \mu \mathrm{m}$

Kermacaria microspora

14 (13) Spores $18-22 \times 8-9 \mu \mathrm{m}$.

Lemearia silicionla

15 (12) Areoles light brown on dark brown prothallus (Fig. 28): perithecia brown; spores thick walled (11.5) 15-23

(27) $\times(4) 6-8(1+) \mu \mathrm{m}$

Verrucaria internigrescens

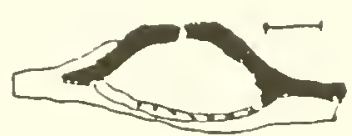

a

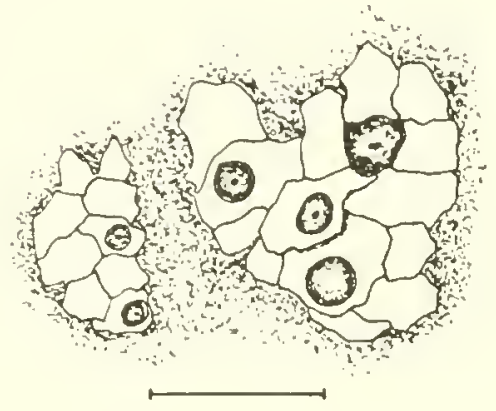

$\mathrm{b}$

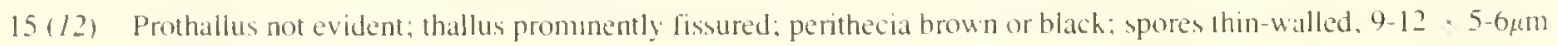
(Fig. 29)

Figure 2x. - it. lertical section of perithecium. Scate is $0.1 \mathrm{~mm}$. b. Thallus of Verrucaria mernigrescens. Sicale is 1 mus.

lérncaria ceuthecarpa

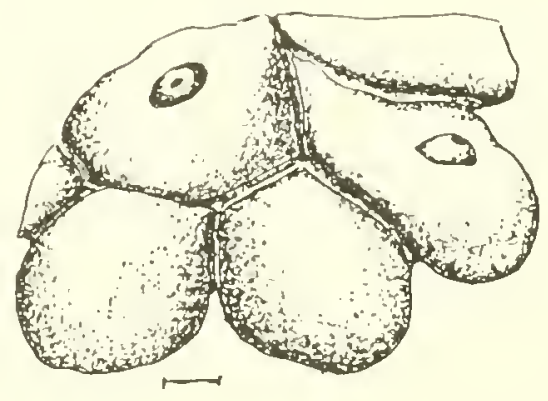

Fipure 29. - ma Vertical section of peritheciums. Ssale is 19.1 mm. b. Thallus of Verrucario ceuthocarpa. hale is $11.1 \mathrm{~mm}$.

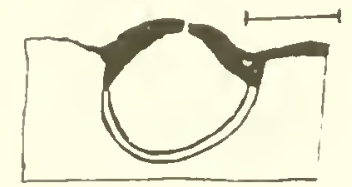

a 
Figure $30 .-$ Areolate thallus. Scale is $1 \mathrm{~mm}$.

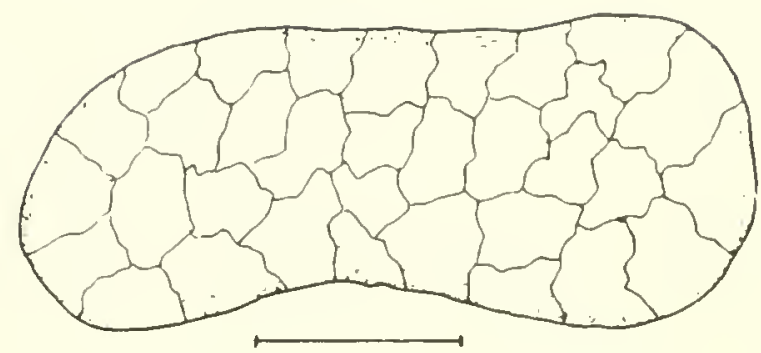

16(1) Thallus not areolate.

Figure 31.-Areoles burdered hy juga. Scale is $0.1 \mathrm{~mm}$.

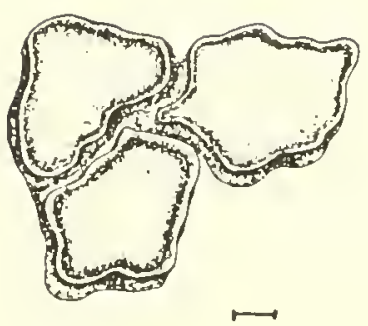

17 (16) Areoles not bordered by juga (Fig. 32)

Figure 32.-Areoles without juga. scale is $0.1 \mathrm{~mm}$.

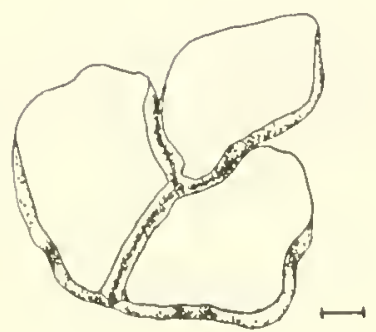


18 (17) Perithecia usually immersed, ostiole border frequently rased, spores $9-12 \times 5-6 \mu \mathrm{m}$; juga rarely limited to borders of areoles, usually scattered within areoles (Fig. 33): thatlus more translucent wer than dry

Verrucaria degelii

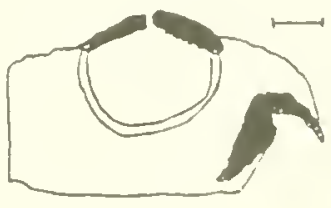

a

Figure 33.-a. Vertical section of perithecium. Scale is $0.1 \mathrm{~mm}$. b. Thallus ut lerrucaria degelii. Scale is $1 \mathrm{nmm}$.

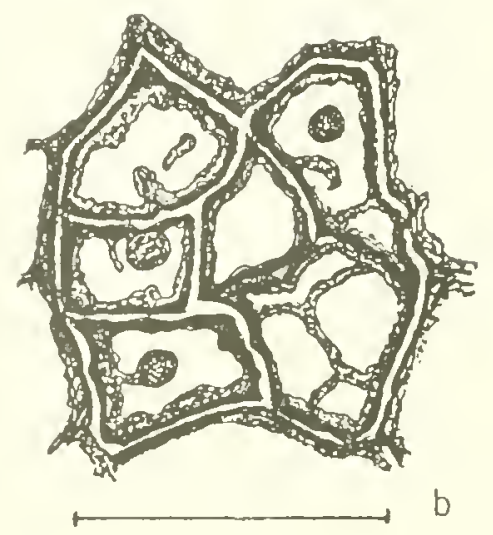

18 (17) Perithecia elevated. often craterous, juga formung a reticulate pattern (Fig. 34); thallus opaque dry, translucent wet

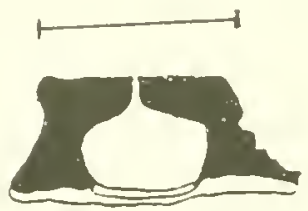

a

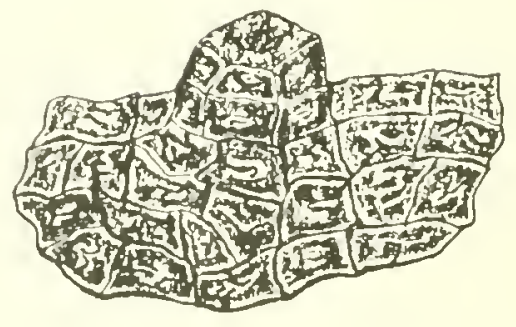

Figure 34.-a. Sertical ection of perithecium. Scale is $1 \mathrm{~mm}$. b. Thallus of Verrucaria amphibia. (Specimen illustrated is thicker and stored fonger than that in Fig. $39 \mathrm{~h}$. I Scale in $1 \mathrm{~mm}$

I9 (17) Juga appeanng as pegs protruding from thallus and also to some extent on perithecia; thallus nmose-areolate. usually blackish-brown and opayue (wet or dry); perithecia often large. 0.3-0.7 mm diameter, immersed or elevated. gently sloped to rising abnuptly, sometimes depressed on top (Fig. 35); spores 10-20 7 - $10 \mu \mathrm{m}$. . . . L'errucaria maura
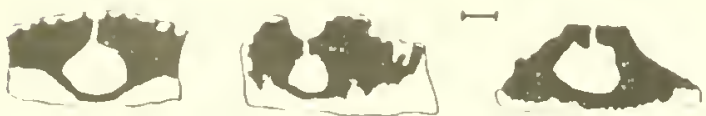

a

Fipure 35.-a. Vertical sections of peritbesium. Scale in 0.1 $\mathrm{mm}$. h. Thallus of Verrucaria maura. Scale is $1 \mathrm{~mm}$.

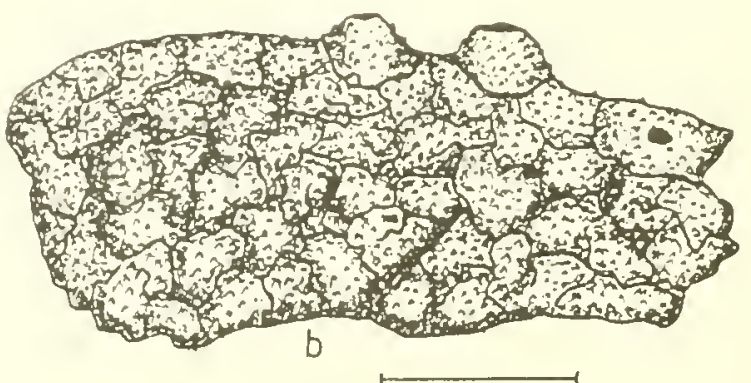


19 (17) Juga raised or mmersed, appearing as usually irregular and often hranched rudges often merging with or continuing over perithecia, if immersed appearing as black spots when wet; thallus blackish-brown, hecoming brown to amher and translucent when wet; perithecia spreading and irregular at base, up to $0.3 \mathrm{~mm}$ diameter (Fig. 36);

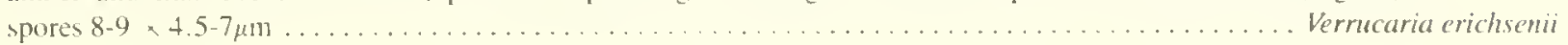

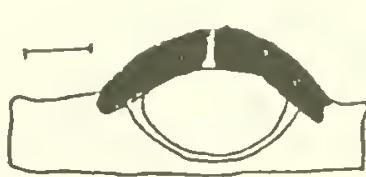

a

Figure 36,-a. Vertical section of perithe cium. Scale is $0.1 \mathrm{~mm}$. h. Thallus of Verracaria erichsenii. Scale is $1 \mathrm{~mm}$.

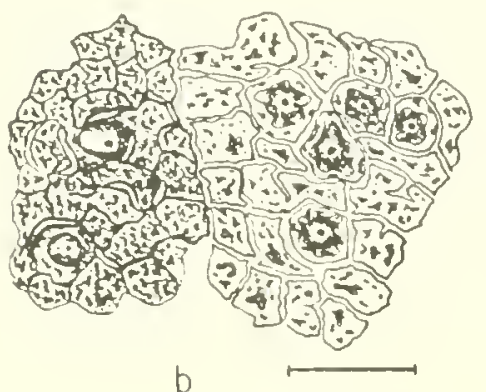

b

20 (16) Perithecia immersed, spores 9-12 $\times 5-6 \mu \mathrm{m}$; juga appearing as long sharp black ridges on borders of thallus, sometimes extending across thallus, fissures occasionally develop along juga and simulate areolation; thallus usually

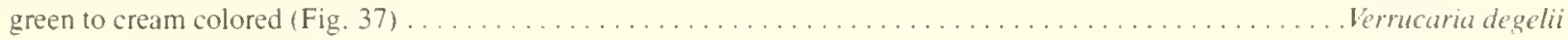

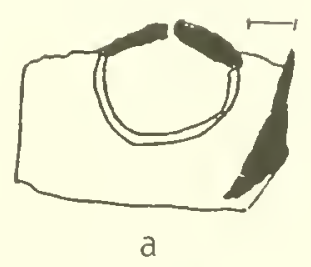

Figure 37.-a. Vertical section of perithecium. Scale is $0.1 \mathrm{~mm}$. b. Thallus of Verrucaria degelii. Scale is 1 mm.

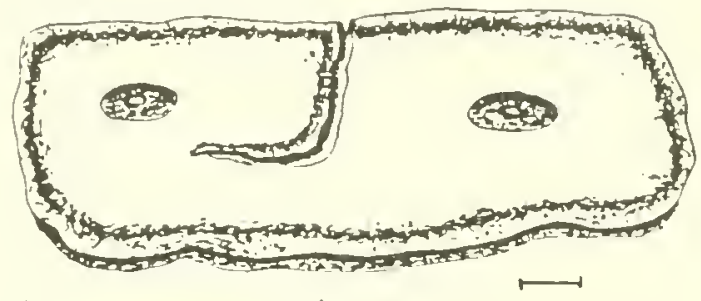

b

Figure 38.-Thallus with prominent raised perithecia.

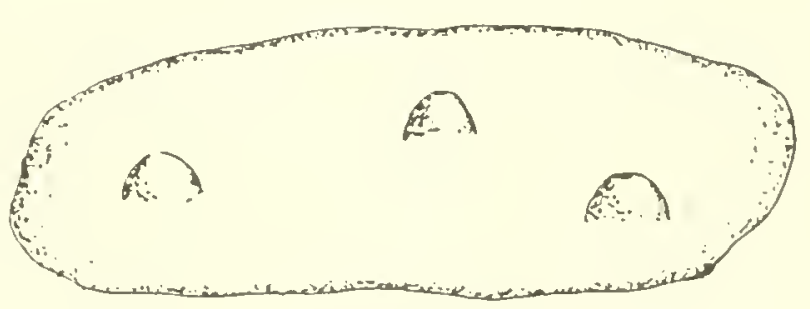

21 (20) Juga inclosing lenticular areas giving appearance of ripples on water. continuing on peritheciun to form reticular pattern. Perithecium elevated, often craterous (Fig. 39); spores $9-20 \times 4-7.5 \mu \mathrm{m} 1 \ldots \ldots \ldots$.......... Vermoaria amphibia

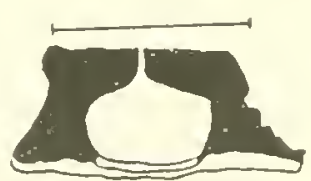

a

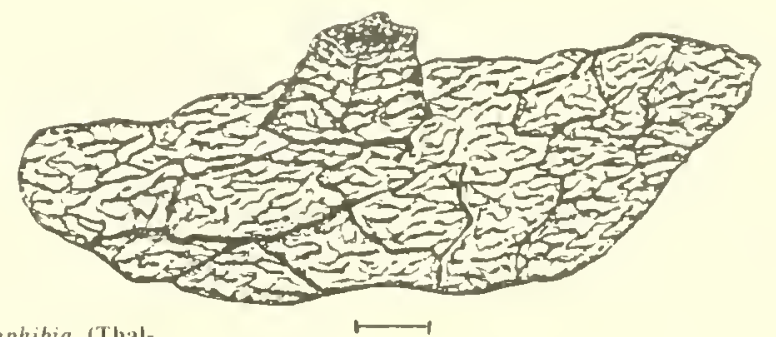

b

21 (20) Juga scattered, not inclosing lenticular areas . 
$22(21)$ Juga appeanng as pegs to usually short ridges, usually straght hut sometimes crescent shaped, sometimes coalescing with perithecium at base; thallus usually dark olve green but lighter and wth fewer juga in shade; perithecia hemispherical, often shiny (Fig. 40): spores 6-11 $\times 3-5 \mu \mathrm{m}$

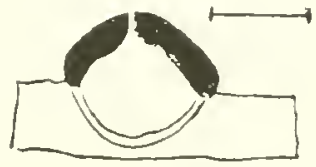

a

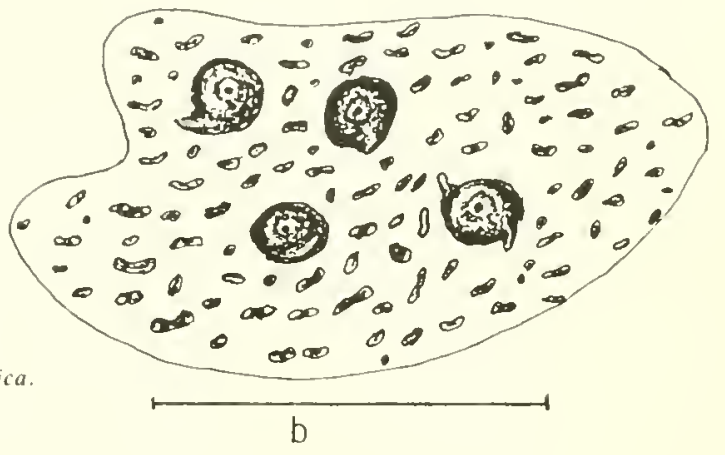

$22(21)$

Juga broader, irregular, and sometimes hranched (Fig. 41).

Figure 41 . - Thallus with broad, sometimes branched juga. Scalc is $1 \mathrm{~mm}$.

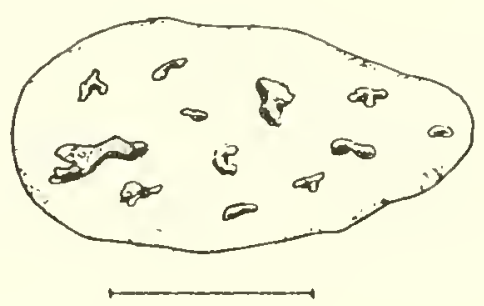

23 (22) Juga conspicuous, highly irregular, frequently hranched, rased or mmersed and appearng as consplcuous blach spots in wet thallus, often merged with perithecta: wet thallus usually brown to amber and translucent (Fig. 42 ): perithecia up to $0.3 \mathrm{~mm}$ dianeter. spores $8.9 \times 4.5-7 \mu \mathrm{m}$

. lemracara erichsema

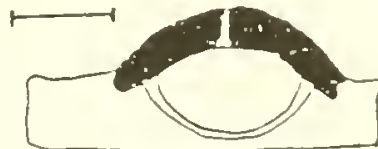

a

Figure 42.-as. Bertical section of perithecium, seate is 11.1 moln. b. Thallus of ferrucara erichseuis. scalc is 1 111

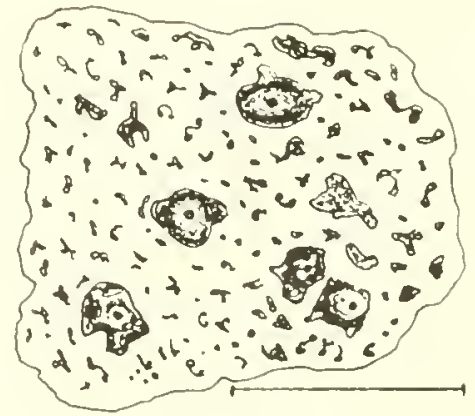

b 
23 (22) Juga promment. blach, and shiny, much thicher than in !' ertchemii. frequently broadened into thick imegular plates. especially at thallus margin; thallus usually grass green but darker in the sun and depigments rapidly in shade or in storage: perithecia typically hemisphencal to globular with flattened tops but may become quite irregular, angular, or dissected (Fig. 43); spores 8-10 $84-6 \mu \mathrm{m}$

Verracaria strianta

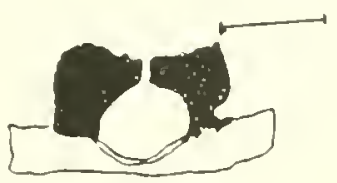

a

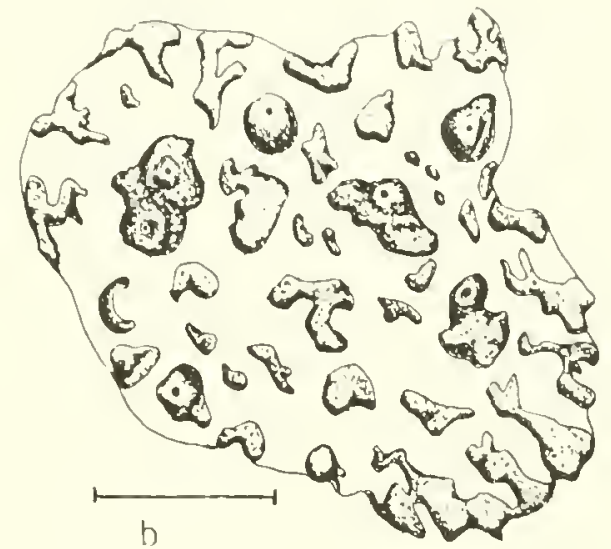

b
Figure 43,-a. Vertical section of perithecium. Scale is $0.1 \mathrm{~mm}$. h. Thallus of lerrucaria striatula. Scale is $1 \mathrm{~mm}$.

\section{ANYOTATED LIST OF SPECIES}

Where distributions were denved from the literature only. author and date are given. All other specimens were examined by the author. Where such specimens were collected by others, the collector's name is given followed by the identilication of the herbarium retaining the specimen. The remaining distributions are from the author's collections.

\section{Genus Arthopyrenia}

Arthopvenia halodves (Nyl.) Arn. Ber. Bayer. Bot. Ges. 1:122 1891. Vermearia halodvtes Nyl. Mem. Soc. Sci. Nat. Cherbourg 5.212. 1857 .

DESCRIPTION: Thallus epilithic (siliceous rock). endolithic (calcareous rock and shells). yellowish if epilthie, greyish or blackish-broun il endolithic. Perithecium almost wholly immersed in substrate or sessile with blach hemispherical to broadly conical involucrellum. 0.15 to $0.5 \mathrm{~mm}$ diameter, excipulum colorless to pale brown. Spores eight per ascus, ovoid, two-celled, one cell usually broader than the other, $9-20 \times 4-7.5 \mu \mathrm{m}$.

Su inscou (1965) considered this to he the only littoral species of the genus and treated A. sublitoralis (Leight.) Arn. . A. foreolara A. L. Sm. and A. gyalectoidea Knowles as synonyms and reported a range of 10-20 $\times 5-10 \mu \mathrm{m}$ in spore size. Richard C. Harris (1975) treats this specien as co. a Prenocollemu.

Arthopyrenia halodite's is often associated with shells or calcareoun rocks but may ilso be found on siliceous rock.

GENERAL DISTRIBUTION: Worldwide on manne shores (Santesson 1939:52-63).

NORTHEASTERN AMERICAN DISTRIBUTION: NEW JERSEY: Cape May Co. CONNECTICUT: New London Co. RHODE ISLAND: Neu port Co. MASSACHUSETTS: Barnstable
Co., Plymouth Co.. Essex Co. MAINE: Cumberland Co., Sagadahoe Co., Hancock Co., Washington Co. NOVA SCOTIA: Yarmouth Co., Dighy Co. . Halifax Co., Victoria Co., Cape Breton Co. NEWfoundLAND: West Coast Section. Northern Peninsula Section. East Coast Section. Avalon Section.

\section{Genus Caloplaca}

All of the littoral species of Caloplaca collected belong to the section Gasparrinia.

Caloplaca marina (Wedd.) DuRietz, Method. Grund. Modern. Pflanzensoziol. 170. 1921. Lecanora marina Wedd. Mem. Soc. Sci. Nat. Sherbourg 19:275. 1875

DESCRIPTION: Thallus orange yellow to red orange. eitrine in shade, orbicular, irregular, or subelfuse, small convex lohes contiguous or, in eenter of thallus, minutely granular or tubereulate, whitish prothallus sometimes visible. Apothecia reddish-orange, 0.5-1.0 mm diameter, plane to convex, margins entire or crenulate. Spores ellipsoid, polarilocular, isthmus about 0.3 length of spore. $10-14 \times 5-7 \mu \mathrm{m}$.

Wade (1965) found this species often associated with Caloplaca thallincola and lerrucuria maura in the British Isles. Caloplaca thallincola has not been collected. however, in the littoral zone of North America. The white hypothallus is seen in young growth hetween the small subconvex lobules.

GENERAL DISTRIBUTION: Nonway. Sweden. Poland (Nordin 1972), Finland (Rasanen 1927). Germany (Erichsen 1957). Novaya Zemy la (Lynge 1928), England (Ferry and Sheard 1969). Wales (Fletcher 1973b). France (Werner MSC)

NORTHEASTERN AMERICAN DISTRIBUTION: MAINE Cumberland Co.. Hancock Co. NOVA SCOTIA: Yarmouth Co. . Digby Co., Shelburne Co., Halilax Co. NEWFOUNDLAND Northern Peninsula Section. 
Caloplaca microthallina (Wedd.) Zahlbr. Cat. Lich. Univ. 7:247. 1931. Lecanora microthallina Wedd. Mem. Soc. Sci. Nat. Cherhourg 19:276. 1875.

DESCRIPTION: Thallus citrine, 1-3 mm diameter, conuprised of scattered lobes on the periphery, scattered granules toward center. forming patches on rocks, lohes convex, 1-2 times as long as broad, tending toward granules near center of patches. Apothecia yellow to pale orange $0.15-0.8 \mathrm{~mm}$ diameter, margins crenulate or entire. Spores ohlong-ellipsoid, polarilocular, isthmus ca. 0.3 the length of the spores, $10-18 \times 5-8 \mu \mathrm{m}$.

Caloplaca microthallina is distinguished by its minute granular thallus forming patches up to $3 \mathrm{~mm}$ diameter and by its citrine color. Wade (1965) found it often associated with lemucaria matra in the British lsles. This also lolds true for North America. This species is not previously reported from North America. In Europe this species is not commonly reported from the littoral zone.

GENERAL DISTRIBUTION: Norway, Sweden, Finland, Denmark (Nordin 1972)

NORTHEASTERN AMERICAN DISTRIBUTION: NOVA SCOTIA: Digby Co., Halifax Co., Cape Breton Co. NEWFOUNDLAND: West Coast Section. Northern Peninsula Section.

Caleplaca scopularis (Nyl.) Lett. Hedwegia 52:242. 1912. Lecanora scomularis Nyl. Flora 66:105, 1883.

DESCRIPTION: Thallus yellow orange to deep orange, radiate. up to $1.5 \mathrm{~cm}$ diameter, lobes narrow, 0.25-0.3 $\times 0.5-2.0 \mathrm{~mm}$, convex, apices crenulate or branched, center of thallus usually thickly covered with apothecia. Apothecia orange, 0.5-0.75 mm diameter, margins entire. Spores ellipsoid, polarilocular, 10-15 $\times 5-7 \mu \mathrm{m}$. isthmus ca. 0.3 the length of the spore.

Caloplaca scopuluris is unique among the littoral Caloplacae due to its radiating thallus. Wade (1965) indicated that this species resembles a small form of $C$. heppiana or $C$. thallincola but is distinquished hy ellipsoid spores and the submonlsform nature of the upper parts of the paraphyses.

GENERAL DISTRIBUTION: Novaya Zemlya (Lynge 1928). Nonway, Sweden, Denmath (Nordin 1972), Finland (Rasanen 1927), Germany (Erichsen 1957), Japan (Nylander 1890).

NORTHEASTERN AMERICAN DISTRIBUTION: MAINE: Cumberland Co. Hancoch Co. NOVA SCOTIA: Halilax Co, Vicmia Co. NEWFOU NDLAND: West Coast Secton. Avalon Section

Caloplaca verreculifera (Vain.) Zahlbr. Cat. Lich. Unis. 7:272.1931. Placodium vermatifera Vainio in Med. om Gron. $30: 313,1905$

DESCRIPTION: Thallus oralnge or vellow, up to $3 \mathrm{~cm}$ diameter. or dispersed, lohes 3-5 num long. convex, center of thallus areolate. granular, isidia globose. spores oblong-ellipsoid, polarilocular, isthmus cat 0.3 length of spore. 9-14 $<4-6 \mu \mathrm{m}$.

Specimens of this species. previously unreported from North America, were identified for the author hy J. Poelt. It is easily confused with Caloplaca gramulosa which also has globose isidlat hut has smaller rosettes of $1-1.5 \mathrm{~cm}$ and shorter lobes of about $2 \mathrm{~mm}$ (Poelt 1969).

GENERAL DISTRIBUTION: Norway, Sweden, Finland, and Siberia (Nordin 1972).

NORTHEASTERN AMERICAN DISTRIBUTION: MAINE: Sagadahoe Co., Hancock Co. NEWFOUNDLAND: West Coast Section

\section{Genus Lecanora}

Lecanora granaii Magn. Ann. Cryptog. Exot. 5(1):21. 1932.

DESCRIPTION: Thallus of irregular whitish-grey large granules. $\mathrm{KOH}+$ yellow: nedulla with small erystals. Apothecia concave to plane, thalline margin regular to crenulate; hymenium dark reddish-brown, I+ dark blue: epithecium with small crystals, insoluble in $\mathrm{KOH}$. Spores eight per ascus, oblong-ovoid. $11-18 \times$ 6-8.5 $\mu \mathrm{m}$.

Little of this species was collected since it extends down only into the upper limits of the littoral zone. The scant material collected conforms to the original material described from a log on a sea beach by Magnusion (1932).

GENERAL DISTRIBUTION: Washington (Magnuson 1932), British Columbia (Brodo MSC).

NORTHEASTERN AMERICAN DISTRIBUTION: MAINE: Sagadahoc Co. NEW YORK: Suffolk Co, (Latham MSC). NOVA SCOT1A: Shelhurne Co. NEWFOUNDLAND: West Coast Section.

\section{Genus Lichina}

Lichina confinis (O. Mull.) Ag. Sp. Algar. 1:105. 1821. Lichen Confinis O. Mull. Icon. PI. Daniaw 5:5, 1872.

DESCRIPTION: Thallus fruticose, branches rounded in cross section, blackish-brown, phycobiont Calothrix, Ascocarps terminal, globose, perithecoid, small ostioles. Spores colorless. simple ovoid, $15-24 \times 12-15 \mu \mathrm{m}$.

Lichina confinis, appearing as black tufts in the upper limits of the littoral zone. is the only fruticose lichen found in the area included in this treatment.

GENERAL DISTRIBUTION: England (Ferry and Sheard 1969). Wales (Fletcher 1973h), Finland (Rasanen 1927), Germany (Degelius 1939). Italy (Jatta 1909-1911), Norway (Havaas MSC), Sweden (Degalius MSC).

NORTHEASTERN AMERICAN DISTRIBUTION: MASSACHUSETTS: Esser Co. (Tuckerman 1882). NOVA SCOTIA. Cape Breton Co. (Lamb 1954). NEWFOUNDLAND: East Coast Section. Northern Peninsula Section. West Coast Section.

\section{Genus Stigmidium}

Stignidium marinum (Deak.) Swins. Lichenologist 3:55. 1965. Sageder marina Deak. Ann. Mag. Nat. Hist. 1. 12:40, pl. 4, f. 13. 1954 
DESCRIPTION: Parasymbiont on littoral Verncariae, especially $V$. mucosa and $V$ microspora, lacking a visible thallus of its own. Perithecia usually resembling that of host lichen, totally immersed on $V$. mucosa and hemispherical on $V$. microspora. Involucrellum black with pigment extending into hyaline excipulum. Spores eight per ascus. two-celled with each cell often divided by pseudosepta, upper cell usually slightly wider than the lower, 10-15 $\times 3.5-5 \mu \mathrm{m}$

The perithecia of Stigmidium are easily confused with that of the host. Stigmidium, however, has two-celled spores of 10-15 15.5 $5 \mu \mathrm{m}$. Swinscow (1965) reported spores 10-15 $\times 4-6 \mu \mathrm{m}$. The combination Stigmidium marinum was made by Swinscow when he united Arthopyrenia marina (Deitk.) A. L. Sm and A. leptotera (Nyl. ) Arn. Neither of these species appear in the North American checklist (Hale and Culberson 1970) nor did Swinscow (1965) report a specmen from North America. This, therefore, represents a new record for North America.

GENERAL DISTRIBUTION: Germany, Finland, Ireland. Jersey, England (Swinscow 1965).

NORTHEASTERN AMERICAN DISTRIBUTION: MAINE: Cumberland Co., Hancock Co. NEW JERSEY: Ocean Co. NEWFOUNDLAND: Avalon Section.

\section{Genus Verrucaria}

The species of this genus form crusts which may be continuous or form scattered patches, rimose areolate or divided into discrete areoles or lobes. The thalli vary in thickness from 20 to $500 \mu \mathrm{m}$, and may be almost completely transparent to entirely opaque. In some species, the transparency of the thallus may be enhanced by wetting, while others remain opaque when wet. The thalli nay be smooth or roughened by dark points or ridges. The ridges. called juga (Santesson 1939), vary in length. width, and thickness. The exact origin and ontogeny of the juga is not known but it appears that they originate at or just below the surface of the thallus. In the author's experience, they do not extend to the substrate except at the edges of the areoles. Often a distinction is made in keys between point and ridge forms of the juga, but it is common that the points are nerely peaks on inconspicuous or hidden ridges.

The perithecia of all of the littoral Verrucariae, with which the author has worked, have a dark involucrellum which may spread widely or be closely appressed to the excipulum. This darhening may extend into the lower excipulum, terminating a short distance below the involucrellum proper or it may not extend into the lower excipulum. The darkening may occur intermittently or continuously throughout the lower excipulum. This darkenıng is given considerable taxonomic importance by Servit (1954) and by Erichsen (1957) but Swinscow (1965) discounted this importance on the grounds that it is highly variable within a species. The author concurs with Swinscow in this view. Perithecial size is not. in itself. very useful in distinguishing species. Perithecium diameters vary generally between 0.05 and $0.7 \mathrm{~mm}$ and these dimensions overlap considerably between lerrucaria species. Although vertical seetions are illustrated in the key, none is claimed to be typical for there is much variation in many. if not all species.

Santesson (1939) has noted the high variability of spore size in littoral pyrenolichens and suggested that they should not be given great taxononic importance. All spores in Verrncario are simple and hyaline. For the most part, the spores are thin walled and of similar size, occurring eight per ascus. Verrucaria internigrescens and $\boldsymbol{V}$. silicicola are the notable exceptions to the above in northeastern North America. The spores of $\boldsymbol{V}$. internigrescens are thick walled and those of $V$. silicicola are unusually large. The remainder are ovoid to reniform and exhibit overlapping size ranges between species.

Verrucaria amphibia R. Clem. Ess. Var. Veg. Andalucia 299. 1807.

DESCRIPTION: Thallus contunuous to rimose areolate, black when dry. translucent green to amber when wet. with irregular black ridges often enclosing Ienticular areas $50-100 \mu \mathrm{m}$ thick. Perithecia large (13-16 mm), prominently elevated, often flattened or concave on top, vertical and horizontal ridges forming reticular pattern, lenticular areas often enclosed by ridges at base: excipulum hyaline to partly darkened below. Spores hyaline, ovoid, 7-19 $\times 4.7 .5 \mu \mathrm{m}$

This species might readily be confused with $V$. marra. Both species have dark thalli with juga forming pegs or ridges and with robust perithecia. However, they are easily distinguished on closer examination. Whereas $V$. muura tends to have points raised above the thallus, $V$. amphibia tends toward ridges. The ridges tend to enclose lenticular areas on a dry thallus giving the impression of ripples on water. When wet, $\boldsymbol{V}$. amphibia becomes more translucent and light colored against which the black ridges become contrasted. The thallus of $\boldsymbol{V}$. maura remains dark when wet except on very thin juvenile specimens. The thallus of $V$. amphibia tends to be continuous whereas that of $V$. muluratends to be rimose areolate but in nejther case are the characters absolute. Areolation appears to develop and increase with age in V. amphibia. Verrucaria umphibia produces large, steep sided perithecia often strongly depressed on top. a form also produced in some instances by $V$. maura. Such perithecia of $V$ amphibia have two characteristics not demonstrated by $V$. maura; whereas $V$. maura may have many fine points or pegs covering the perithecium, the design on $V$. amphihia is a reticulum of vertical and horizontal ridges. Also, where the $V$. amphibia perithecium meets the thallus, the ridges tend to enclose areas of ovoid shape and appear light and translucent when wet (see the Key).

Vernicaria amphibia is little discussed in literature. Santesson? says that it is not known from Scandinavia, although it occurs in England. Ferry and Sheard (1969) included V. umphibia in their key but did not deal with it in detail. The author lirst became acquainted with it by examining herbarium specimens and his measurements should not he regarded as limits due to the small amount of material examined. There is no prior report of this species lrom North America

GENERAL DISTRIBUTION: England (Ferry and Sheard 1969), Wales (Fletcher 1973a). Germany (Ullrich MSC).

NORTHEASTERN AMERICAN DISTRIBUTION: NEWFOUNDLAND: East Coast Section, Avalon Section.

Vermucaria ecastrecarpa Wahlenb. in Ach. Suppl. Meth. Lich. 22. 1803.

DESCRIPTION: Thallus brown, rimose areolate, glabrous, forming discrete areoles or lobes, ridges absent, perithecia sub-

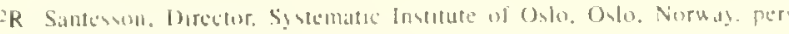
cummun Nuember loge 
merged, $0.1-0.15 \mathrm{~mm}$ wide, involucrellum usually brown, excipulum hyaline to dark below: spores hyaline, ovond 8-10, $5-8 \mu \mathrm{m}$.

Vermoaria ceuthocarpa is easily confused with lerracaria degelii when either is modilied by environment or when its structure is obscured by epiphytic algae. The clefts of I' cethucurpa may become darkened and, on cursory examination. may resemble the dark ridged border of areoles of l' degelii. Careful examinaton is needed to observe the absence of ridges. Conversely sometimes the ridges are scant on a thallus of l' de'gelii and it may by mistaken for that of $V$ ceuthocurpa.

Perhaps the greatest obstate to correct identilication is obucuring of surlace detail by epuphytic algae. Portions of questionathle thalli should be flooded with water to soften and expand the algae. II details are still obscured, the flooded porton can be scrubbed with a small water color brush. True nidges are farly resistant to such gentle abrasion and will persist until the thallus becomes ton softened by the water to maintain its integrity.

According to Santessons key (1939), the prime diagnowic teature of I' degelit vs. I' ceuthorarpa is the presence of ndges on l' degelit.

The author finds that wo other features are quite useful. The hest of the two is tendency for liatness to concavity hetween ridges of an areole of $V$. degelii compared with the convexness of areoles and branches thereof on I'. cetuhocarpa. I'erracaria couthocarpa is truly glabrous. Further, from the limited material in the author's three North American collections it also appean that the involucrellum of $V$. ceuthecumatends to be brow'n whereas that of $V$ degelii is distinctly black.

GENERAL DISTRIBUTION: Northern Europe, Spitshergen. Bear Island. Novaya Zemlya, Siberia, Bering Strats, Greenland, Kerguelen. Antarctica (Lamb 1953): Washington U.S.A. (collected by Fink and deternined as Lemucuria neara by Zahlbruckner MSC).

NORTHEASTERN AMERICAN DISTRIBUTION: NEWFOUNDLAND: Ean Coast Section

\section{lemrucariudegelii R. Sant. Ark. Bot. 29A (10):31. 1939}

DESCRIPTION: Thallus rimuse, forming lobes or discrete areoles, amber, brown or black when dry, amber to brown when wee. prominent black ndges bordering areoles and often perithecia, thin to thick (100-320 mm). Perithecia sunken to prominently raised, 0. 1 $0.25 \mathrm{~nm}$ drameter, excipulum hyalıne. Spores hyaline, oxold $9-1.3$. $5-6 \mu \mathrm{mm}$.

Though published in 1939, this species wa know nonly from Norway unel the authori collections, thus there are few specmens and little study of ecolongy upon which to base conclusions about envirnmental influences on variatums. It is reasonable to alssume, however. that the nature of vanatums is consistent with that seen in other Verucarias. If so. color would be lighter in shade forms than sun forms and ridges woukl be fewer and thuner in thate forms than an sun forms. This kinel of variatuon is probibly the cause of confusion of

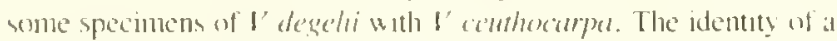
robust upecimen of I' degelit is heautufully clear. However, the ridges may heerome uant and the upecinen strongly resembles the morpho"Ype of I' cemberarpe with darkened clefts between areoles. A rec-

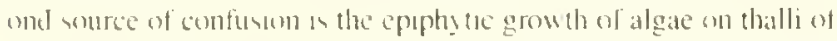

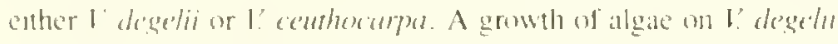
can obecure ndges and produce the glabrous appearance of l'? 'cuthocurpa. Such a grouth can also protuce as shade condetion for the underlyng thallus and reduce the growth of ndges. On the other hand, a growth of dark algae on I? ceuthocarpa, especially when dry; may obscure the color and glabrous nature of the thallus and give the illusion of ridges on the edge of areoles. One cannot over-emphasize the impontance of detecting and removing such epiphytic algae!

The thallus of 1: degelii varien greatly in thickness and transparency depending on age or extent of development. It is almost always areolate, with only one known exception. In that case, a rather large area of snowoth, continuous thallus was surrounded by a raised black ridge and a crack, also bordered by a black rased ridge, extended inward toward the center. At the edges ol thes patch of thallus was more thallus divided inte typical discrete areoles with similar black borders. More commonly a young thallus is thin, nearly transparent. smouth and brown to tan. It is areolate and is often divided into lohes by a dendrits pattern of grooves. In such a thallus, the grooves are usually hyaline.

The ontogeny of these lichens has not been studied and must be inferred from observations of what could as casily be the results of conditions of growth an of aging. It appears, however, that older thalli thicken and develop discrete areoles, usually with black borders and frequently with black lines connecting them with the penthecium. These areas of blackness then seem to proliferate under some conditions to produce unelevated patterns or raised juga. Sonetimes the black area extends beneath the perithecium and sometimes it does not.

The penthecum is commonly mmened, with or without rased ridgen around the osiole. At times there is a consex area raised anund the ostiole. The author bas seen promunently raised convex perithecia on the same thalius as sunken perithecia. The degree of penthecial elevation appears to be a vanable character of the species.

Spores are owoid but sometimes pointed when young. A clear spot conmonly, although not always, appears in the center of the younger spores. Santesson (1934) reported the range of spore sizes for lerrucaria degelii as 10-13 - 5-6 $\mathrm{m}$. Which is consistent with that observed by the atthor.

\section{GENERAL DISTRIBUTION: NORWAY' (Santesmn 1939).}

NORTHEASTERN AMERICAN DISTRIBUTION: MAINE: Hancock Co., Washington Co. MASSACHUSETTS: Essex Co. NOVA SCOT1A: Yarmouth Co., Dighy Co., Halifax Co. NEWFOUNDLAND: West Coast Section, Northern Peninsula Section. East Coast Secton. Avalon Section.

Verrmearia ditmarsica Erichs. Schriften Naturwiss. Verems Schleswig-Holstem 22:90. 1937

DESCRIPTION: Thallus entire, olivaceous, wh peas to shont ridges, thin $(20-50 \mu \mathrm{m})$, opaque to translucent when dry. more translucent when wet. Perithectal slightly dome-shaped to globose (usually hemisphencal), 0.1-0.25 mm diameter. usually shıny: excipulum lyaline to dark below. Spores ovoid to reniform. color-

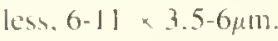

The thatlus of Vermatria dimmarica is usually olvaceous, hut the darkness varles w th light exposure. In bnght light the thallus is dark olve and if grom 1 an the shade it is a very light olise green it usually is rather tramsparent to translucent. The tramspareney is increased by wetting upon examinatum. Short, mostly straight ridges are characteristic on the thallus. These become reduced in size and frequency in the shade moditication. In thu reduced cond1tum it is easily contuned whthe shade modification of 1 erich- 
senii and especially with $f^{\prime}$ smionth whose color is atso smilar. Ridges often merge with the perithecia at the base.

The perithecia are convex to hemispherical and usually shiny. Darkness of the lower excipulum is a highty variable factor. Generally some carbonaceous granules tend to extend below the involucrellum and may continue sonewhat throughout the lower involucrellum (see the key). However, the species should not be characterized as having an involucrellum that is dark below, a view adopted by Erichsen (1957).

GENERAL DISTRIBUTION: Germany (Erichsen 1957), NotWay (Santesson MSC).

NORTHEASTERN AMERICAN DISTRIBUTION: MAINE: Cumberland Co. Sagadahoc Co.. Hancock Co. RHODE ISLAND: Newport Co. MASSACHUSETTS: Plymouth Co., Essex Co. NEW HAMPSHIRE: Rockingham Co. NOVA SCOTIA: Yarmouth Co., Digby Co. Shelburne Co., Halifax Co., Victoria Co. NEWFOUNDLAND: West Coast Section. Northern Peninsula Section, East Coast Section. Not previously reported from Nonh America.

Vermatuia erichsenii Zsch. in Erichs. Verh. Bot. Verems Prow: Brandenburg 70: 192. 1928.

DESCRIPTION: Thallus entire or areolate, black to blackishbrown dry, amber and more translucent when wet, roughened by rows of pegs or ridges; ridges often branched, sometimes submerged in thallus and visible only when wet: thallus $30-70 \mu \mathrm{m}$ thick. Perithecia elevated, conical to hemispherical, spreading in irregular pattern at base, often with pegs or ridges as on thallus. 0.1-0.3 mm diameter, excipulum hyaline below. Spores ovoid, colorless, 8 -9 $9+4.5-7 \mu \mathrm{m}$.

Verrucaria erichsenii denonstrates considerable thallus variation. It is usually considered to be clearly rimose or arcolate. Typically this is so but it is not uncommon to find a thallus of $l^{\prime}$ erichsenii continuous in an especially wet enviromment, where the thallus becomes thick and gelatinous. When dry the thallus is ustrally blackish-brown to black. A grey morphotype with a texture like that of graphite was collected in the Narragansett Bay area. When moistened during examination the thallus increased in transparency, one of the hest tests of questionable thalli. When wetted they reveal a pattern of black markings typical of the pattern of ridges usually seen above the surface. The thallus of $V$ ' erichsenit typically has short, often branched irregular ridges or rows of points, frequently confluent with or continuing up over the perithecia. Ridges are longer than wide and rarely very high. In extreme circumstances ndges become higher and sharper forming cusps and arêtes. In other extremes they maly be immersed within the thallus to be revealed only by wetting.

The most consistent character of the perithecium appears to be the irregular spreading base which seems most pronounced when viewed from above a wet thallus or when the thallus has been peeled from the rock and placed on a slide and illuminated from below: The diameters of perithecia tend to fall between 0.1 and 0.3 $\mathrm{nm}$.

Zschacke (1934) and Erichsen (1957) both list a spore range of 8 $12 \times 5-7 \mu \mathrm{m}$ which agrees with the author's observation.

GENERAL DISTRJBUTION: Germany (Erichsen 1957), British Columbia (Ohlsson MSC), Sweden (Santesson MSC), Norway
(Santesson MSC). Wales (Brodo MSC). Scotland (Brodo MSC).

NORTHEASTERN AMERICAN DISTRIBUTION: MAINE: Cumberland Co., Sagadahex Co., Hancock Co., Lincoln Co. (Merrilt MSC). Washington Co. MASSACHUSETTS: Essex Co. Bristol Co. (Willey MSC), Plymouth Co. Barnstable Co. RHODE ISLAND: Newpon Co., Washington Co. CONNECTICUT: New London Co. NEW HAMPSHIRE: Rockingham Co. NOVA SCOTIA: Yarmouth Co., Digby Co., Shelburne Co. Halifax Co., Victoria Co., Cape Breton Co. NEWFOUNDLAND: West Coast Section, Northern Peninsula Section. Avalon Section.

V'erncaria imermigrescens (NyI.) Enchs. Vern. Bot. Vereins Prov. Brandenburg 70:193. 1929. l'errucuria aethobola var. Intermigrescens Nyl. in Brenner, Meddeland. Soc. Fauna Fl. Fenn $13: 125.1886$

DESCRIPTION: Thallus of brown areoles connected by darker brown prothallus. Perithecia brown, convex, 0.2-0.34 mn diameter. excipulum hyalıne or intermittently darkened below Spores hyaline, thick walled, fusitorm, (11.5) $15-23$ (27) $\times$ (4) $6-8$ (14) $\mu \mathrm{min}$

The brown prothallus, thallus, and perithecia are distinctive. The thallus is thin by comparison with other areolate forms such as $b$. mura and $l$. cemhocarpu. The spores are distinctive, being lusiform and thich walled. Erichsen (1957) reported a spore range of $15-27 \times 7-12 \mu m$. As indicated above. spores were found in the North American colleetions as large as reported by Erichsen but they were bloated and of atypical shape. Most spores seen were in the range of $15-23 \times 6-8 \mu \mathrm{m}$. Erichsen (1957) listed this species as both littoral and nonlittoral, therefore, it may be assumed to be facultative in its habits. This species was collected at only one locality in North America and this is the first record from North America.

\section{GENERAL DISTRIBUTION: Germany (Erichsen 1957).}

NORTHEASTERN AMERICAN DISTRIBUTION: NEWFOUNDLAND: Avalon Section.

Verrucuriar manra Wahlenb. in Ach. Suppl. Meth. Lich. 19. 1803.

DESCRIPTION: Thallus dark, usually blach to brownish-blach, sometimes green, opaque (wet or dry), rimose areolate, usually with small blach pegs or points (sometimes obscured by epithallic algae), thin to thick $(75-300 \mu \mathrm{m})$. Perithecia small to large (usually large) $0.3-0.7 \mathrm{~mm}$ dianeter, sunken to prominently raised tops rounded to concave. may be covered visibly by pegs, excipulum entirely black below: Spores ovoid, hyaline 10-20 $\times 7-10 \mu \mathrm{m}$

Verrucariomanra is probably one of the most widely used names anong the littorat lichens. This often leads to the report of the species based on the most cursory examination. The species is highly variable and its varation has probably been best understood and described by Suntesson ( 1939, footnote 2). The author can add little to the description of variation provided by Sintesson (footnote 2) and would like here to merely record his eoncurrence and quote Santessoni description the material quoted was provided for the author in Swedish by Santesson) of typical I? menure as: "1. Indistınct or dark prothallus. 2. Definite blach thallus, 3, areolate thallus. 4. thallus surface with distinct but little comspicuous ponts. 5 . 
rounded conical conspicuous perithecia, 6. rounded, not umpressed penthecia tops, and 7 . spores with a width of 7-10) mic. (length 10 19 or at most $20 \mathrm{mic}$.)"

Santesson contunues by describing seven deviations with which he associates names of varleties or what he considers to be synonyms:

"1. With white or light brown clear prothallus. '1.' sschackeano Erichs.:

2. With green-gras or greenish black thallus. "var, fumosocine" rea Vain."

3. With connected or triflingly lissured thallus. ' $V$. sommo Wedd.

4. Thallus surface with many strongly conspicuous pegs. ' $V$. aractina Wg.'

5. a. With perithecia almost entirely sunken into the thallus. " $V$. malmei Serv.

b. With hemispherical to nearly spherical perithecia. 'var. prominula Vain.'

6. With elearly impressed, frequently somewhat irregular perithecium tops. 'I'. trachinodes Norm." 'I' havenit Erichs, "var aractinudes Vain. "f evoluta Th. Fr."

(?7. Spores with a width of 11-15 mic. "V. funmarkica Zsch.')."

The author has seen all of these forms in North America except " $V$. finmmarkica." A common variation results from frequent washing with water from rain or waves which causes the thallus color and texture to become obscured by epithallic algae which produce a smooth greenish surface.

GENERAL DISTRIBUTION: Novaya Zemyla (Lynge 1928), Finland (Rasanen 1927), Germany (Erichsen 1957), Spain to Finland (Degelius 1935), Italy (Jatta 1909-1911), India (Awasthi 1965), Japan (Nylander 1890), Greenland. Iceland, Bear Island. Spitsbergen, Siberia, Bering Strait, Fuegia, Patagonia. Chile. Falkland Islands, and New Zealand (Lamb 1953), Norway (Santesson MSC), Sweden (Santesson MSC). Wales (Fletcher 1973a), England (Ferry and Sheard 1969). British Columbia (Brodo MSC).

NORTHEASTERN AMERICAN DISTRIBUTION: MAINE: (Plitu USA). NOVA SCOTIA: Yarmouth Co., Digby Co. Shelburne Co. . Halifax Co, Victoria Co., Cape Breton Co. NEW: FOUNDLAND: West Coast Section, Northern Peninsulia Section. East Coast Section, Avalon Section. NEW BRUNSWICK Campobello.

lerrucaria microspura Nyl. Ann. Sci. Nat. Bot. IV. 3:175. 1855.

DESCRIPTION: Thallus usually broun to amber. sometumes green or grey, smoxth thin, $20-30 \mu \mathrm{m}$ continuous or in patches but never areolate, translucent when dry, more transparent when wet. Perithecia dome-sliaped (shightly arched) to hemispherical, sometumes ponted, 0.05-0.3 mm drameter. excipulum entrely hyalıne below: Spores hyaline, rentform to atoid, 6-11 $1 \times 3-5 \mu m$.

lerrwark microspora is characterized by a thin. normally brown to amber thallus which is enther contunuous or in scattered patches but never areolate. The thallue is devoid of pegs or ridges but may contan artificts that might superticlally resemble peges or ridges. In some instances tests have proven these to be pernthectal remans. The thallu hecomes translucent to quite transparont when wet. Erichsen (1957) recognized a var. laetevirens as characterized by a leek green thallus which is less transparent. The author has also observed this in material from the southern part of its range in North America as well as a dark grey thallus in the same area. The dark grey thallus has a color and texture resembling graphite used in pencils. Upon wetting, the darh color disappears.

The pertihecia are brown to black and may be shiny or dull. Their shape may range from that of a slightly arched dome to more nearly hemispherical and pointed. The diameter of the penthecia is reported as 0.15-0.25 mm (Lamb 1953), 0.1-0.3 mm (Santesson footnote 2), 0, 2-0.3 mm (Zschache 1925), and 0.2-0.3 $\mathrm{mm}$ (Enchsen 1957). Erichsen (1957) also recognized var. friesiuca as having at smaller perithecia of only 0.1-1.15 mm diameter. The author measured 230 perithecia ( 10 each from 23 specimens) and found a range of $0.08-0.28 \mathrm{~mm}$ except for a single collection in which the range was $0.16-0.48 \mathrm{~mm}$ with 4 out of 10 exceeding $0.3 \mathrm{~mm}$. In no other collection did the diameter exceed $0.3 \mathrm{~mm}$. Clusters of small or larger perithecia may be found and due to the normal patchy appearance of the thalli, one may be tempted to consider such patches as distinet species. Perithecium size should not be considered of taxonomic significance in this species.

Spores of $t$ microspores are thin walled and will change shape some what with osmotic changes. Generally they are ovoud to slightly rentform. The species name infers smallness of spores, but this is not noticeably different from $I$. dimarsica and $V$ striatula. Spore sizes have been reported as 7-12 $\times 4-5 \mu \mathrm{m}$ (Lamb 1953). 7-1] $\times 5-7 \mu \mathrm{m}$ (Zschacke 1925), and 7-11 $\times 4-5 \mu \mathrm{m}$ (Erichsen 1957). Enchsen (1957) also recognized var. mucosula Sands. with spores $5-9 \times 4$ $9 \mu \mathrm{m}$. The author's spore measurements give a range of 6-11 $\times 3$ $5 \mu \mathrm{m}$

GENERAL DISTRIBUTION: Germany (Erichsen 1957), England (Ferry and Sheard 1969), Greenland, Japan, Chile, Antarctica (Lamb 1953), Wales (Fletcher 1973a). Noruay (Santesion MSC), Scotland (Brodo MSC), Australıa (Willis MICH).

NORTHEASTERN AMERICAN DISTRIBUTION: MAINE: Cumberland Co., Sagadahoc Co. Hancock Co. MASSACHU. SETTS: Essex Co., Plymouth Co., Barnstable Co. RHODE ISLAND: Newport Co. CONNECTICUT: New London Co. NEW JERSEY: Ocean Co, Cape May Co. NOVA SCOTlA. Colchester Co.. Cumberland Co. . Yarnouth Co., Digby Co., Shelburne Co.. Victuria Co. NEIVFOUNDLAND: West Coas Section. Northern Peninsula Section. East Coast Section

lérncaria mucosa Wahlenh. in Ach. Suppl. Neth. Lich. 23. 1803.

DESCRIPTION: Thallus grass green to hlachih-green, smooth and tough, continuous. often w ith neeral crachs in he rbariun specimens. 130-150 $\mathrm{mm}$ thich, usually opaque ( wet or dry); Juga absent: prothallus, is present, whitish. Penthecta subnerged to slightly raised, sometumes with prominent ostules surrounded by chumne?. excipulum clear below, involucrellum 0.05-0.2 mm diameter. Spores smple. colorleus, usually owold, $8-11 \times 4-5 \mu \mathrm{m}$

Thallus of this species is easily recognized an the field or in the herbarium. In old herbarium specimen it is broun Lpon drying it deselops crachs that are strictly necral antifacts not to be confused wh the rimose areolation typical of 1 : morre. A whitinh prothallus us often seen around a thallus on smooth rock.

Perithecia are normally flush to slightly raised or sunken. When npe. the mboluerellum tends to cvaginate stomewhat presenting a 
conspicuous ostiole wth a short chumney around it. One often sees whitish pits in the thallus which are the remains of old perithecia divested of their involucrella.

The thallus of $V^{\prime}$ meconct is qute agaressive and often grows oner

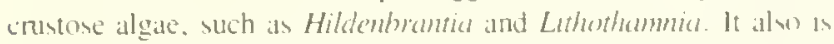
conmonly found growing over other Verrucariate where the perthecia of the overgrown material project through the thallus of l: mucosa causing a potential source of misidentification.

Spores af $l$ 'mucosal are not distunctive in either shape or size. Sancismon (1939) reponted the size of spores to be highly varlahte. 7-15 $\times 4-8 \mu \mathrm{m}$

Pycnidia are quite common on l'. mucosat thalls. They appear as sits ringed wath brown and occur widely scattered or in clusters. It 1s not uncommon to find mounds made up of aggregated pyendia.

GENERAL DISTRIBUTION: Sweden, Norway, Finland. Iceland, Faroe Islands, Germany. Ireland. France (Santesson 1939). England (Ferry and Sheard 1969). Wales (Fletcher 1973a). Greenland, Siberia, Fuegia, Aukland Islands. Campbell 1sland. Neu Zealand (Lamb 1953). British Columbia (Brodo MSC)

NORTHEASTERN AMIERICAN DISTRIBUTION: MASSACHUSETTS: Essex Co. Plymoth Co. NEW HA.IPSHIRE: Rochingham Co. MAINE: Cumberland Co.. Sagadahoc Co., Hancock Co., Lincoln. Co. (Merril MSC). Washington Co. NOWA SCOTIA: Colchester Co., Cumberland Co. Yarmouth Co., Digby Co. Shelburne Co., Halifax Co., Victoria Co. Cape Breton Co. NEWFOL NDLAND: Northern Pennsula Section. East Coant Section. Avalon Section.

Lemucaria silicicolu Fink in Hedrich. Mycologia 25(4):305, 1933

DESCRIPTION: Thallus brownish, continuous to patchy. not areolate. Perithecia shallow domes to hemspherical, 0.15-0.4 mm broad: excipulum hyaline to dark belou. Spore hyaline. 18-22 x 8-4 $4 \mathrm{~mm}$.

The author: knowledge of this species is limited to the examination of available herbarium specimens collected and hnown only from Long I land, N. Y. The material seen resembled I. microspora to a considerable degree. The thallus was brownish and patch. The perithecs. for the nost part, were shallow domes. Hedrick (1933) gave 0.15-0 + nm as the diameter of penthecia and those seen by the author fell within this range. The salient characteristic of this species is the spore size. listed by Hedrick (1933) as 19-22 $\times 8$. $9 \mu \mathrm{m}$. The author was unable to find spores but Brodo (1968) reported the range as $16-25 \times 6-10 \mu \mathrm{m}$.

NORTHEASTFRN AMERICAN DISTRIBUTION: NEW YORK: Suffulk Co. (Latham MSC), (Brodo MSC)

termatria sriamla Wahlent. in Ach. Suppl. Neth. Lich. 23. 1803

DESCRIPTION: Thallus entire. light to darh green usually opaque when dn. more translucent when wet, contanng numerous hlack, rather broad ndges often branched, ridges especially common at thallus margins. Perithecia hemispinerical to globular, wlien 1rregular. Mattened and/or dissected, shing, 0.07-0.3 mom diameter. excipulum byaline to entirely dark below. Spores word, may be pointed at once end. $8-10 \times 4-6 \mu m$

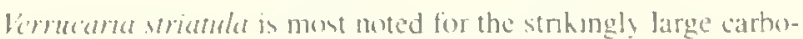
naceous strictures termed juga by Santesson (1939). The juga rise above the thallus and tend to he broad and often branched. They commonly encompass a perithecum. Near the edge of the thallus they often radiate out from the ecnter. markng the leading edge of thallus lobes. They are different from the ridges of l' erichsonit and $V$ dimasica, being more like tlattened plateaus and buttes than nartou ridges.

The thallus is normally a bright green when fresh but darkens in more intense sunlight. It fades quickly in the shade. In the herbar1 um the thallus soon becomes colorless and sarcely visible, a conditun caumng early workers to think that the juga were the enture thallus (Santesson 1939). The thallus in continuous but often shows necral crachs upon drying

The perithecia are otten amorphous. coalescing with juga or appeanng as spheres frequently with flattened tops. The perithecia otten are cracked or dissected and usually a shiny blach.

In the shade modification the penthecia become more nearly spherical or may be alongated vertically. Juga hecome reduced. causing the shade moditication of $V$. striatulat to resemble $V$. ditmarsica. However. even in the shade nodification, juga usually retain their flatness and are reduced in size, but still are broad by comparison with other ridged species. Perithecium diameters are in the general range of $0.05-0.3 \mathrm{~mm}$. Zschache (1934) listed the spore range as $8-12 \times 4-5 \mu \mathrm{m}$ and Erichsen (1957) as $8-11 \times 4-5 \mu \mathrm{m}$.

GENERAL DISTRIBUTION: Sweden, Norway, Dennark, lceland. Ireland. France, Span, Portugal (Santesson 1939). Wales (Fletcher 1973a). Scotland (Brodo MSC). England (James MSC).

NORTHEASTERN ANIERICAN DISTRIBUTION: MASSA CHUSETTS: Essex Co., Plymouth Co. RHODE ISLAND: Newport Co. NEW HAMPSHIRE: Rochingham Co. MAINE: Cumberland Co., Hancock Co. NOVA SCOTIA: Yarmouth Co. Digby Co.. Shelburne Co. Halifax Co. Victoria Co. NEWFOUNDLAND: West Coast Section. Northern Peninsula Section. East Cuast Section. Avalon Section. NEW BRLNSWICK: Grand Manan (W. R. Taylor M1CH).

\section{Genus Xanthoria}

Samhoria candelaria (L.) Th. Fr. Gen. Heteroluch. Europ. 6] 1861. Lichen candelarius L. Sp. PI. J141. 1753

DESCRIPTION: Thallus foliose, light gold, diffuse or forming rosettes. $\mathrm{KOH}$ - purple. Lohes small $(0.2-0.5 \mathrm{~mm}$ broad) plane to convex, lacerated. sorediate. soredia mostly apual. lobes tend to rue off substrate. Apothecia ca. I mm broad with thalline margin Spores eight per ascus, polarilocular. 9-13 - 4-6 $4 \mathrm{mr}$,

This species superticially resembles members of the genus Candelana for which it 1 named but differs in reactoon to $\mathrm{KOH}$ and spore ty pe. The Candelariac are $\mathrm{KOH}$ - and the spores are not polarilocular. There is also a resemblance between Ximthoria cundelariat and $X$. fallax when the latter displiys lobe widths at the narrow end of the range for that species. However, in such a cane the location of suredia will distingush them. In $X$. camdelama the soreda are apical or lamt. nal as opposed to the labrose mode in $\mathbb{X}$. fallax

GENERAL DISTRIBUTION: Nitha (Krog 1968). South Dakota (Wetmote 1967). Nevada (Imshaug 1957). Washngton (Howard 1950). Utah (Wetmore MSC). Californa (Neucomb 
MSC), Britısh Columbıa (Ohlsson MSC), west central Canada (Bird 1970), Cuba (Montagne 1838-42), Greenland (Lynge 1932), Novaya Zemlya (Lynge 1932). France (Harmand 1905), Germany (Erichsen 1957). Nepal (Awasthi 1965). England (Ferry and Sheard 1969).

NORTHEASTERN AMIERICAN DISTRIBUTION: NOVA SCOTIA: Cape Breton Co. NEWFOUNDLAND: Avalon Section.

Ximhoria elegans (Link) Th. Fr. Lich. Arct. 69. 1860. Lichen elegams Link. Ann. Naturges. 1:37. 1791.

DESCRIPTION: Thallus foliose, red orange to citrine, nsing off of substratc at least at tips. $\mathrm{KOH}+$ purple, forming rosettes about $2-5 \mathrm{~cm}$ diameter, lobes nodular-convex, including lips. Apothecia orange yellow to red orange, about I-2 mm broad, Spore colurless. polarilocular, $10-13 \times 5-8 \mu \mathrm{m}$.

Upon cursory inspection this species may appear to be crustose but it does have a developed lower contex and lifts ofl the substrate at least at the tips. The lobes have a tubular appearance but of quite irregular width and thickness, giving it a rather nodular appearance. Like $X$ parietina it is devoid of soredia.

GENERAL DISTRIBUTION: Washington (Howard 1950). Alaska (Ḱrog 1968). South Dakota (Wetmore 1967), New Mexico (Rudolph 1953), Arizona (Nash MSC), Colorado (Wetmore MSC), Wyoming (Shushan MSC), Montana (Imshaug MSC). lowa (Imshaug MSC), Michigan (Jmshaug MSC). Minnesota (Fink MSC), Wisconsin (Malachowski MSC). New York (Brodo MSC). Mexico (Beaman MSC), Manitoba (Gillis MSC). Northwest Territory (Prest MSC). Nova Scotia (Lamb 1953). Greenland (Lynge 1932). Finland (Rasanen 1927), India (Awasthi 1965), China (Magnusson 1940), New Zealand (Nylander 1888), Ontano (Wang MSC), leeland (Copeland MSC).

NORTHEASTERN AMERICAN DISTRIBUTION: MAINE: Sagadahoc Co., Hancock Co. NOVA SCOTIA: Digby Co., Shelburne Co., Halifax Cu., Victoria Co. Cape Breton Co. NEWFOUNDLAND: West Cuast Sectuon, Northern Peninsula Section.

Xamhoria parietina (L.) Th. Fr Lich. Aret. 67. 1860. Lichen parinims L. Sp. Pl. 1143. 1753.

DESCRIPTION: Thallus folose, orange to cilrine, radiate, often rosettelike, $\mathrm{KOH}+$ purple, lobes llat, wrnkled, ca. $1 \mathrm{~mm}$ broad, usually forked at the tips, soredta absent. Apothecia numerous, ca. $5 \mathrm{~mm}$ hroad, plane 10 concave $u$ ith thin thalline margin disappearng with age. Spores eight per aseus, polarilocular, colorless, $10-13 \times 6-9 \mu \mathrm{m}$.

This widespread oceanic speces a easily distinguished from all other littoral Xanhoriac by its relatively broad, thin, distinetly urinkled thallus dis ided dichotomously at the tips. The apotheetat often contrast with the thallus by being nore red colored.

GENERAL DISTRIBLTION Greenland (Lynge 1937). No aya Zenlya (Lynge 1928). Sweden (Degelsur 1935). Finland (Rilsinen 1927). Italy (Jatta 194)9-1911). Inda (Awasho 1965). Cuba (Mlontagne 1838-42), Tenente (Inwhalug MSC). England (Ferry and Sheard 1969), Wales (Fletcher 1937b), Spain (W \& C Culberson MISC).
NORTHEASTERN AMERICAN DISTRIBUTION: MIAINE: Cumberland Co., Sagadahoc Co. Hancock Co. MASSACHUSETTS: (Fisher MSC). NEW YORK: (Brodo 1968). NOVA SCOTIA: Halifix Co., Yarmouth Co., Digby Co., Shelburne Co.

\section{SELECTED BIBLIOGRAPHY}

AW.ASTHI, D D

1965 Caldague of the lubens Irom Indad. Nepal. Pakistati. and Ceylon Nona Hedurgas. Bethetix. Suppl 17.137p

BIRD, C D

1970) Key (1) the lichens at weat central Canada The Herbarsum. Dep

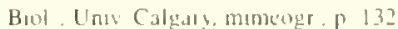

BRODO. I 11

.1968 The lichens of Long lwand. New York A regetatunal and Ilormate

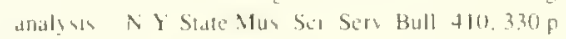

DH GHLILS. C

143.5 Dis az:anmbe tement der srauch-und-laub-flechten hora wan Shandinaven Actu Phytogengr Suec. 7 1-411

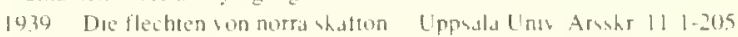

ERICHSFN.C F F

1957 Flechlen flora von Nonduestedurchland Gublal Fivcher verlag. Stutgart, p 1.411

FFRRY, B W. and J W SHEARD

1969 Zonation al supralitaral lichens on shore around the Dale Penusuld. Penthroheshire Field Siud $341-67$

FLETCHER, A

1973a The ecology of marne (hitoral) luchen un smae ruch stures al Anglese: Luhonolugist 9 .368-400

j47.3t The ecology of narilume (supralifloral) lachens on wome rocks shores of Anglesey Luhenolugas 5401.422

HALt, $M 1$ t, Jr, and W L CUI.BERSON

1970. A fourth checklist of the Juhen of the continental United States and Canuda Bryologest $73+49.543$

HARMAND, L J.

1905 Luhens de France Fpinal. Parls + 609

HARRIS R

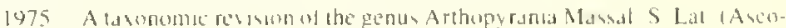

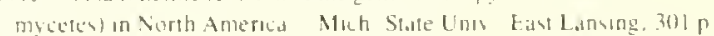

HFDRICK. 1

1933 New genera and specten of luhene tron the herharium on Bruce Finh 1 Mrcologia $25 \quad 303-310$

HOWARD, G E

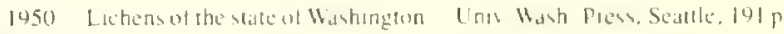
INISHALG. H A

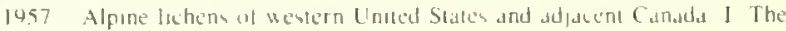
natrolichen Bryolugat on 177-272

JAT TA. A

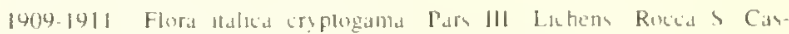

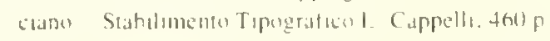

KRUG. H

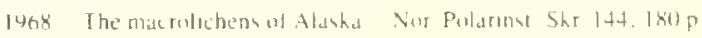

I AMB. I . I

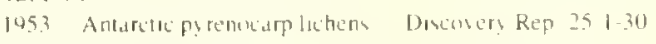

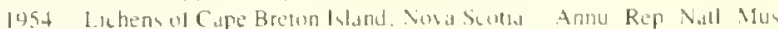
Can $1.322,34 \cdot 313$

LINGI. B

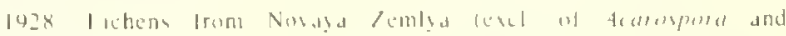

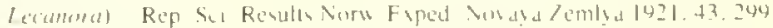
p

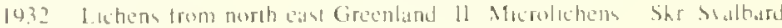
Lhalet 8 \&! 1.143

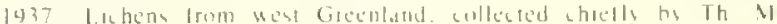
Fries Medut Groml 118isi. 2250

11 a G N S S S $)$ A H

1932 I whem Irom wastor Dorthamerka mand! Wahongen and Alathat Ann ('rypuge but 501 ) lo-3

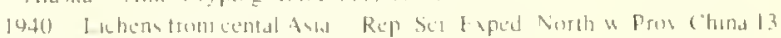
$\operatorname{lon} \mathrm{p}$

IONTACINE. J I

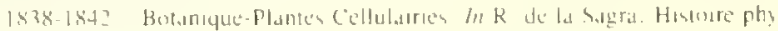

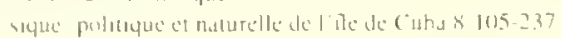


NORDIN I

1972 Caloplarased Gasparrinus Nurdeuropa Uppala.p 1.184

NYLANIDER, H

Is88 Luhenes Novae Zelandac Pars, P 1.156

1890 Luhenes Japonade Paris. p. 1.122

POE1T. J

1464 Bestmmungaschlussel Europascher Flechten 3. Cramer. Lehre, P 1-254

RASANEN, $\because$

1427 Uher Flechtensundurte und Flechtensegetatum im wealluchen Nord. andand Ann Suc Zool. Bur Fenn Vandmo 7 1-201?

RUDOLPH. E D

1953. A controbution to the lichen flora ol Arsound and New Mewsos. Ann Mo Bot Giard 406.3 .72

SANTESSON, R

1439 Amphbiou pyrenolichens! Arh But 29A(J) 1-67

SERVIT, MI

1954 Ceshoslovenshé lasenjnihy celed: Verrucaraceac. Nahiadatelstvı Ceshoulovenshe Ahademe Ved. Prana
SWINSCOW, T D V

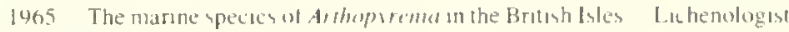
355.64

TLICKERMAN, F

1882 A syopusut the Nurth American iuchens Part l comprising the Par

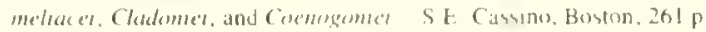

WADE. A E

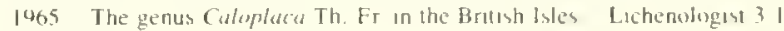
28

WEBER, W A

10h2 Environmental moditcation and the laxunosny of the crustuse luchens Sven Bul Tudihr 56 293.333.

WETMORE, C M

1967 Lichens of the Black Hullsof Susth Dahota and Wyonung Publ Mus Mich State Unar. Bul Ser $3209-464$

ZSCHACKE, H

1925. Die mitteleuropaschen Verrucarlaceen IV Hedurga 65.46-64

1934 Eplglocacede, Verrucartaceac und Dermatocarpaceae. Rahenhorst h hryptogamen-tlora 1. part 4 645 P 


\section{SYSTEMATIC INDEX}

Artheprerench halodves

Caloplaca marina

Caloplaca vermonliferes

Caloplaca microthallina

Caleplaca scopularis..

Lecanora gramsio

Lichima (') nfinis

Stigmielium marrimm

lerracaria amplithica

lemearia cenhocarpa

lermucaria degelii.

\author{
$1,2,3,9,15$ \\ 8.15 \\ 8.16 \\ 8.15 .16 \\ 8. 16 \\ 2. 7,16 \\ . 2, 6 \\ 9.16 \\ 12. 13.17 \\ $10,17,18,19$ \\ 3. $12,13,18$
}

Lemearies dimarsuca

2. 3.14 .18 .20 .21

Lémearia erichsernit

lemearia internigrescens

2. 3, 13, 14, 18, 19, 21

. 10.17,19

lérnacaria matures . . . . . .

lerrucarias microspera. . .

lérnucaria macosa. .

lérnararia silicicola.

lérmacuria striatula . . . . . . .

Xémhoria comdeleriat

Xammoria elegems . . . . . .

Eamhora parietina
$3.10 .12,15,16,17,19,20$

$3.10 .17,20.21$

$2,4,10,17,20,21$

$\ldots \ldots 10,17,21$

. 2.4.15,19.20,21

. .......6, 6, 21

. . . . . . 7, 22

7. 22 


\section{ACKNOWLEDGMENTS}

Preparation of the "Manne Flora and Fauna of the Northeastern United States" "s being coordinated by the following Board:

Coordinating Editor.

Melbourne R. Carriker, College of Marine Studies, University of Delaware, Lewes, DE 19958.

Edıtorial Advisers:
Marie B. Abbott, 259 High Street, Coventry, Conn. (Formerly with Gray Museum, Manne Biolog1cal Laboratory, Woods Hole, Mass.)

Arthur G. Humes, Boston University Marine Progran, Manne Biological Laboratory, Woods Hole, Mass.

Wesley N. Tiffney, Retired, Boston University, 226 Edge Hill Road, Sharon, Mass.

Ruth D. Turner, Museum of Comparative Zoology, Harvard University, Cambridge, Mass.
Roland L. Wigley. Retired. Natıonal Manne Fish encs Service, Northeast Fisheries Center, NOAA, Woods Hole, Mass

Robert T Wilce, Department of Botany, Unversity of Massachusetts, Amherst, Mass.

The Board established the format tor the "Manne Flora and Fauna of the Northeastern Unted States," invites systematists to collaborate in the preparation of manuals, reviews manuscopts, and advises the Scientific Editor of the Nituonal Manne Fishenes Service.

Thanks ate expressed to Henry A Imshaug for his assistance in research and advice in prepanng the manuscript. Thanks are also expressed to Melbourne R. Carriker for continued assistance in later research stages and manuscript preparation. Richand D. Wood was very helpful in the field work in the Narragansett Bay area. Helen S. Taylor, Brian M. Taylor, and Sheryl M. Taylor contrbuted both in the research for and preparation of the mauscrpt. Adeje Denison and Ralph Gorton aided in the preparation of the final manuscript. 


\section{COORDINATING EDITOR'S COMMENTS}

Publicatıon of the "Marine Flora and Fauna of the Northeastern Unuted States" is most tmely in vieu of the grou ing univeral emphass on environmental work and the urgent need for more precise and complete identuficaton of coastal organisms than has been avalable It is mandatory, wherever posstble, that organisms he identified accurately to species Accurate scientific names unlock the great quantucs of bological informatton stored in libranes. obviate duplication of rexearch already done. and of ten make pousible prediction of attnbutes of organıms that have been inadequately studled

Ronald Taylor started his research on lichen in 1964 at Michigan State Universtly where he later received his doctoral degree. He was then. and is now. on the faculty of Lansing Communty College at Lansing. Mrch.

Preparation of this manual was supported in part by a grant from the Environnental Protection Agency to the Editorial Board of the "Manne Flora and Fauna of the Northeastern United States." Work on the "Marine Flora und Faunat of the Northeastern Unted Stutes" by the Coordinating
Editur th supported by the College of Marne Studien. Unwersty of Delat Ware

Manuats are atvallable trom the following

Supernntendent of Documents, LIS Governnzent Printıng Oflice, Washing. 10n. DC 20402, for a charge

User Service Branch. Library and Information Services. Division D822, Washongton Scuence Center. Buildung 4, Rockible, MD 20852, at no charge al long at the supply lasts.

National Technical Information Services. US Department of Commerce. 5285 Port Royal Roud. Springtield, VA 22161, enther as paper copy or macrofiche, for a charge

Manuals are not copy righted, and so may he photocopied from the NOAA Techncal Report NMFS Circulars atallable in most major libranes.

The manuals on far published in the NOAA Technical Report NMFS Circular weries are listed belou by author, tutle, circular number, and NTIS accessuon number

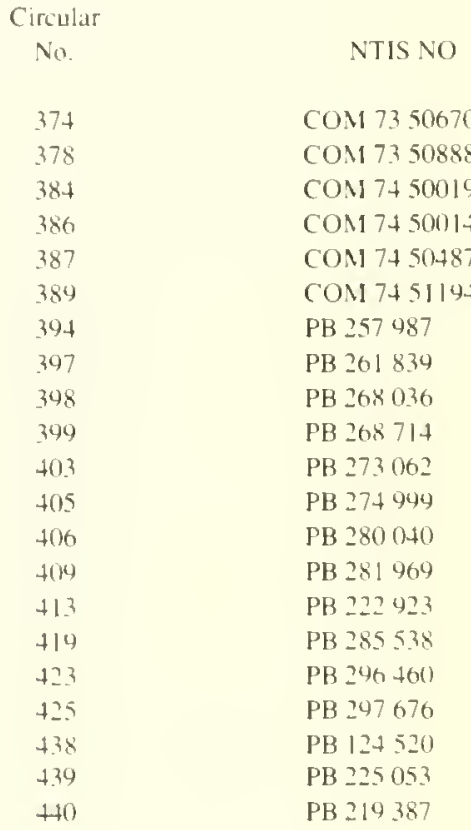

COOK. DAVID G. . and RALPH O BRINKHURST. Annelida: Oligochaeta BORROR, ARTHUR C. Protozoa: Ciliophora

MOUL. EDWIN T. Higher Plants of the Marine Fnnge.

McCLOSKEY: LAWRENCE R. Pycnogonida

MANNING, RAIMIONDB Crustacea Stomattopoda

WILLIAMS. AUSTON B Crustacea Deciapoda

POLLOCK. LELAND W Tardigrada

LARSON, RONALD J. Cnudana Scyphozai.

CAVALIERE, A. R. Higher Fungl: Axcomycetes, Deuteromycetes, and Bdsidmycetes

COULL, BRUCE C. Copeporda: H.ITpacusorda

CUTLER, EDWARD B Sipuncula

PAWSON. DAVID L. Echinodermata Holothurondeat

HO. JU-SHEY Copepoda: Lernaeopodidae and Sphy nudde

HO. JU-SHEY Copepoda Cycloponds Parasuctic on Fishes

CRESSEY. ROGER F. Crustacea: Branchusu

BOVEE, ElGENE C.. and THOMASK SAWYER Protozod Surcodnai. Ammehate

WATLING, LES. Crustacea. Cumacea

ZULLO. VICTOR A Arthropeda Cimpedia

CAIRNS, STEPHEN D Cnidaria Sileractınia.

TODD. RUTH, and DORIS LOW Protozoa Sarcodena Benthrc Forammitera

BUSH. LOUISE F. Turbellana: Acocla and Nemertodermatuda

$+40$

$\mathrm{PB} 219387$

TAYLOR, RONALD M. Lichens (Asconycetes) of the Intertidal Region 




\section{NOAA TECHNICAL REPORTS NMFS Circular and Special Scientific Report-Fisheries}

\section{Guidelines for Contributors}

\section{CONTENTS OF MANUSCRIPT}

First page. Give the title (as concise as possible) of the paper and the author's name, and footnote the author's affiliation, mailing address, and ZIP code.

Contents. Contains the text headings and abbreviated figure legends and table headings. Dots should follow each entry and page numbers should be omitted.

Abstract. Not to exceed one double-spaced page. Footnotes and literature citations do not belong in the abstract.

Text. See also Form of the Manuscript below. Follow the U.S. Government Printing Office Style Mamual, 1973 edition. Fish names, follow the American Fisheries Society Special Publication No. 12, A List of Common and Scientific Numes of Fishes from the United States and Canada, fourth edition, 1980. Use short, brief, informative headings in place of "Materials and Methods."

Text footnutes. Type on a separate sheet from the text. For unpublished or some processed material, give author, year, title of manuscript, number of pages, and where it is filedagency and its location.

Personal communications. Cite name in text and footnote. Cite in footnote: John J. Jones, Fishery Biologist. Scripps Institution of Oceanography, La Jolla, CA 92037, pers. commun. 21 May 1977.

Figures. Should be self-explanatory, not requiring reference to the text. All figures should be cited consecutively in the text and their placement, where first mentioned, indicated in the left-hand margin of the manuscript page. Photographs and line drawings should be of "professional" " quality - clear and balanced, and can be reduced to 42 picas for page width or to 20 picas for a single-column width, but no more than 57 picas high. Photographs and line drawings should be printed on glossy paper-sharply focused, good contrast. Label each figure. DO NOT SEND original figures to the Scientific Editor; NMFS Scientific Publications Office will request these if they are needed.

Tables. Each table should start on a separate page and should be sell-explanatory, not requiring reference to the tevt. Headings should be short but amply descriptive. Use only horizontal rules. Number table footnotes consecutively across the page from left to right in Arabic numerals; and to avoid confusion with powers, place them to the left of the numerals. If the original tables are typed in our format and are clean and legible, these tables will be reproduced as they are. In the text all tables should be cited consecutively and their placement, where first mentioned, indicated in the lefthand margin of the manuscript page.

Acknowledgments. Place at the end ol text. Give credit only to those who gave exceptional contributions and not to those whose contributions are part of their normal duties.
Literature cited. In text as: Smith and Jones (1977) of (Smith and Jones 1977); if more than one author, list according to years (e.g., Smith 1936; Jones et al. 1975; Doe 1977). All papers referred to in the text should be listed alphabetically by the senior author's surname under the heading "Literature Cited"; only the author's surname and initials are required in the author line. The author is responsible for the accuracy of the literature citations. Abbreviations of names of periodicals and serials should conform to Biological Abstracts List of Serials with Tille Abbreviations. Format, see recent SSRF or Circular.

Abbreviations and symbols. Common ones, such as mm, $\mathrm{m}, \mathrm{g}, \mathrm{ml}, \mathrm{mg},{ }^{\circ} \mathrm{C}$ (for Celsius), $\%, \% \circ$, etc., should be used. Abbreviate units ol measures only when used with numerals; periods are rarely used in these abbreviations. But periods are used in et al., vs., e.g., i.e., Wash. (WA is used only with ZIP code), etc. Abbreviations are acceptable in tables and figures where there is lack of space.

Measurements. Should be given in metric units. Other equivalent units may be given in parentheses.

\section{FORM OF THE MANISCRI'I}

Original of the manuscript should be typed double-spaced on white bond paper. Triple space above headings. Send good duplicated copies of manuscript rather than carbon copies. The sequence of the material should be:

\author{
FIRST PAGL \\ CONTENTS \\ ABSTRAC'T \\ TEXI \\ LITERATURE: CITED \\ TEXT FOOTNOTES \\ APPENDIX \\ TABLES (provide headings, including "Table" and Arabic \\ numeral, e.g., Table 1.--, Table 2.--, etc.) \\ I IST OF FIGURE I EGENDS (entire legend, including \\ "Figure" and Arabic numeral, e.g., ligure I.-., ligure \\ 2.--, etc.) \\ FIGURES
}

\section{ADDITIONAL. INIOORMATION}

Send ribbon copy and two duplicated copies of the manu script to:

Dr. Carl J. Sindermann, Scientific Editor Northeast Fisheries Center Sandy Hook Laboratory

National Marine Fisheries Service, NOAA

Highlands, NJ 07732

Copies. Fifty copies will be supplied to the senior author and 100 to his organization free of charge. 


\title{
UNITED STATES
}

DEPARTMENT OF COMMERCE

NATIONAL OCEANIC AND ATMOSPHERIC ADMINISTRATION

NATIONAL MARINE FISHERIES SERVICE

SCIENTIFIC PUBLICATIONS OFFICE, FINWR 1

7600 SAND POINT WAY N E

BINC 15700

SEATTLE, WA 98115

OFFICIAL BUSINESS

\section{NOAA SCIENTIFIC AND TECHNICAL PUBLICATIONS}

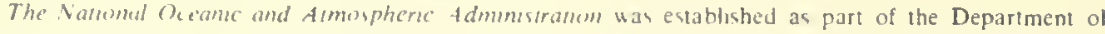

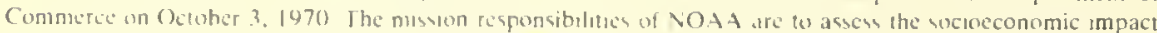
of natural and echnologicat changes in the cnsironment and to monitor and predict the state of the solid Earth. the uccans and their living resources, the atmosphere, and the space environment of the Earth
\end{abstract}

The major components of VOA tegularly produce varou types of scientific and technical informatoon in the following kinds of publications

PROFESSION IL P IPERS - Important definitive rescarch results. major techniques, and spectal invertigations

CONTRACT AND GR INT REPORTS - RepOIS prepured by contractors or grantees under VOA.A sponsorship

ATLAS - Presentation of analyzed data generally in the form of maps thowing distrihution of rainfall. chemical and physucal conditions of oceans and atmosphere, distribution of fishes and marme mammals, ıonospheric conditions, etc.
TECHVICAI SERIICE PUBLICATIONS - Repurts containing data. sbeertations, instructions, etc A partial listing includes data serıals: prediction and outhok peroudical-; technical manuals, training papers. planning reports, and information serials; and miscellaneous rechnical publications.

TECHNICAI. REPORTS - Journal quality with extensıe details, mathematıcal developments, or data listings.

TECHNICAL MEMORA VDUMS - Reports of preliminary. pirtial. or negatıve research or technology results, interm instructions, and the like.

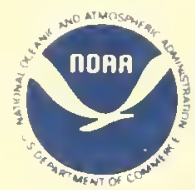

Informotion on availability of NOAA publications can be abtained from

ENVIRONMENTAL SCIENCE INFORMATION CENTER (D822)

ENVIRONMENTAL DATA AND INFORMATION SERVICE

NATIONAL OCEANIC AND ATMOSPHERIC ADMINISTRATION

U.S. DEPARTMENT OF COMMERCE

6009 Executive Boulevord

Rockville, MD 20852 